DANIELLE DA SILVA MENCHACA VEGA

\title{
CARACTERIZAÇÃO DE FITOL E VERIFICAÇÃO DE UMA SEGUNDA VIA DE BIOSSÍNTESE DE FILOQUINONA E TOCOFEROL NOS ESTÁGIOS INTRAERITROCÍTICOS DE Plasmodium falciparum
}

Dissertação apresentada ao Programa de Pós-Graduação em Biologia da Relação Patógeno-Hospedeiro do Instituto de Ciências Biomédicas da Universidade de São Paulo, para obtenção do Título de Mestre em Ciências. 
DANIELLE DA SILVA MENCHACA VEGA

\title{
CARACTERIZAÇÃO DE FITOL E VERIFICAÇÃO DE UMA SEGUNDA VIA DE BIOSSÍNTESE DE FILOQUINONA E TOCOFEROL NOS ESTÁGIOS INTRAERITROCÍTICOS DE Plasmodium falciparum
}

\author{
Dissertação apresentada ao Departamento \\ de Parasitologia do Instituto de Ciências \\ Biomédicas da Universidade de São Paulo, \\ para obtenção do Título de Mestre em \\ Ciências. \\ Área de concentração: Biologia da Relação \\ Patógeno-Hospedeiro \\ Orientador: Prof. Dr. Alejandro Miguel Katzin \\ Versão original
}


DADOS DE CATALOGAÇÃO NA PUBLICAÇÃO (CIP)

Serviço de Biblioteca e Informação Biomédica do

Instituto de Ciências Biomédicas da Universidade de Såo Paulo

@ reprodução total

Vega, Danielle da Silva Menchaca.

Caracterização de fitol e verificação de uma segunda via de biossíntese de filoquinona e tocoferol nos estágios intraeritrocíticos de Plasmodium falciparum / Danielle da Silva Menchaca Vega. -- Săo Paulo, 2013.

Orientador: Prof. Dr. Alejandro Miguel Katzin.

Dissertação (Mestrado) - Universidade de São Paulo. Instituto de Ciências Biomédicas. Departamento de Parasitologia. Área de concentração: Biologia da Relação Patógeno-Hospedeiro. Linha de pesquisa: Malária.

Versão do título para o inglês: Characterization of phytol and na alternative pathway for phylloquinone and tocopherol biosynthesis in intraerythrocytic stages of Plasmodium falciparum.

1. Malária 2. Plasmodium falciparum 3. Vitamina E 4. Vitamina K 5. Fitol I. Katzin, Prof. Dr. Alejandro Miguel II. Universidade de São Paulo. Instituto de Ciências Biomédicas. Programa de Pós-Graduação em Biologia da Relação Patógeno-Hospedeiro III. Título. 
Título da Dissertação:

Caracterização de fitol e verificação de uma segunda via de biossíntese de filoquinona e tocoferol nos estágios intraeritrocíticos de Plasmodium falciparum.

Orientador(a):

Prof. Dr. Alejandro Miguel Katzin.

A Comissão Julgadora dos trabalhos de Defesa da Dissertação de Mestrado, em sessão pública realizada a

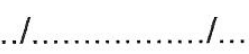
considerou

\section{( ) Aprovado(a) \\ ( ) Reprovado(a)}

Examinador(a):

Assinatura:

Nome:

Instituição:

Examinador(a): Assinatura:

Nome:

Instituição:

Presidente: Assinatura:

Nome:

Instituição: 


\section{CERTIFICADO DE ISENÇÃO}

Certificamos que o Protocolo CEP-ICB N $\mathrm{N}^{\circ} 476 / 11$ referente ao projeto intitulado: "Caracterização de fitol e verificação de uma segunda via de biossíntese de filoquinona nos estágios intraeritrocítos de Plasmodium falciparum" sob a responsabilidade de Danielle da Silva Menchaca Vega, foi analisado na presente data pela CEUA - COMISSÃo DE ÉTICA NO USO DE ANIMAIS e pela CEPSH- COMISSÃO DE ÉTICA EM PESQUISA COM SERES HUMANOS, tendo sido deliberado que o referido projeto não utilizará animais que estejam sob a égide da lei 11.794 de 8 de outubro de 2008, nem envolverá procedimentos regulados pela Resolução CONEP nº196 de 1996.

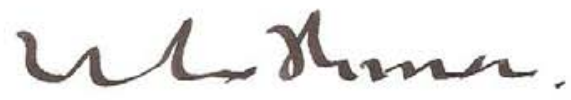

Prof. DR. WOTHAN TAVARES DE Lima Coordenador da CEUA - ICB/USP
São Paulo, 19 de agosto de 2011.

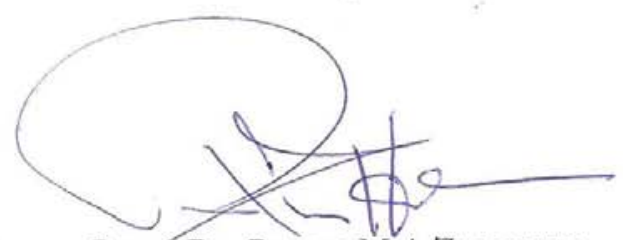

PROF. DR. PAOLO M.A ZANOTTO Coordenador da CEPsh - ICB/USP 
Dedico esta Dissertação de Mestrado a minha mãe Fátima ao meu pai Juan (in memoriam), meus amores. 


\section{AGRADECIMENTOS}

Primeiramente agradeço a Deus, pela vida e pelas oportunidades e desafios que põe em meu caminho.

Agradeço Prof. Dr. Alejandro Miguel Katzin, pelo oportunidade de fazer o mestrado em seu laboratório.

Agradeço a Dra . Emília Kimura pela disponibilidade em colaborar cientificamente.

A Valnice, que nesse tempo foi mais que, foi uma amiga, foi uma segunda mãe. Agradeço também pela ajudar profissionalmente que ela me deu.

As minhas amigas Alejandra, Márcia, Raquel, Rose e Tati pelo companheirismo e amizade de todos os dias.

Aos companheiros de laboratório Alexandre, André, Heloísa em especial ao Rodrigo e Raquel que sempre me ajudaram e contribuíram para a realização desse trabalho.

A todos os meus amigos da Embrapa Gado de Leite, que me deram a primeira oportunidade de aprender sobre a pesquisa e também sobre as coisas boas e simples da vida. De forma especial quero agradecer à Pricila e o Jefferson pelo companherismo, amizade e apoio incondicional.

Aos amigos que construi ao longo da minha vida Adriana, Brenda, João Carlos, Dedi, Leandro, Patrícia Prudencine, Irmã Cristiana, Daniel Zabala, Javier, Dani e tantos outros que sempre torceram por mim.

Aos meus amigos do departamento Andernice, André, Bruno, Carla, Lyslaine, Omar, Robson, Zuleima pelos momentos de alegria e companherismo.

As amiga, Camila Queirós, Stefannie, Cláudia, Ketrin, Maísa e Lívia que me acolheram e me ajudaram quando cheguei a São Paulo.

A amiga Patrícia Lacouth pela amizade contruída e por tudo que faz por mim.

Ao meu amigo Jahn e ao Hermann pela amizade paciência e ajuda na formatação do trabalho.

As amigas Paola e Oneida pelo carinho, amizade e companherismo.

Agradeço a Nathália pelo incentivo de vir fazer o mestrado.

Ao Rafael, um irmão que ganhei neste tempo.

A Professora Dr(a). Ana Maria de Lauro Castrucci, pelo apoio e amizade construída.e aos colegas do laboratório de Fisiologia Comparativa da Pigmentação.

Agradeço as amigas Maria Augusta e a Maria das Graças pelo incentivo e por cuidar da minha mãe.

Agradeço a família da Esperança e a comunidade de Guarará-MG pelas orações.

A amigas Diana, Sara e Belkis, por ajudarem fortalecer a minha fé.

Em memória do meu pai Juan, que não está presente em mais esta conquista, mas que é o meu grande motivador para vencer.

A minha mãe Maria de Fátima, mulher forte guerreira que está ao meu lado em todos os momentos, me ajudando e incentivando, dedicando a mim um amor incondicional.

Ao Edward, que além de ser um grande amigo, hoje é o meu amor e faz meus dias mais felizes. 
"Que os vossos esforços desafiem as impossibilidades, lembrai-vos de que as grandes coisas do homem foram conquistadas do que parecia impossível".

Charlin Chaplin 


\section{RESUMO}

Vega DSM. Caracterização de fitol e verificação de uma segunda via de biossíntese de filoquinona e tocoferol nos estágios intraeritrocíticos de Plasmodium falciparum. [dissertação (Mestrado em Parasitologia)]. São Paulo: Instituto de Ciências Biomédicas, Universidade de São Paulo; 2013.

Nosso grupo identificou vários produtos da via de biossíntese de isoprenóides em Plasmodium.falciparum que é apontada como promissora para o desenvolvimento de drogas antimaláricas, uma vez que esta via não é compartilhada pelo hospedeiro humano. Os compostos isoprenicos identificados nas formas intraeritrocíticas de $P$. falciparum, foram as cadeias isoprênicas ligadas às proteínas (isoprenilação de proteínas), ao anel benzoquinona (Coenzima Q 7-9), além de carotenóides, dolicois (11 e 12 unidades isoprenicas) menaquinona, filoquinona e tocoferol. A filoquinona e tocoferol estão formadas por um anel cíclico e uma cadeia isoprênica o fitil. $\mathrm{O}$ fitol em plantas é originado da degradação da clorofila, mas como ainda não existem evidências da presença de clorofila no parasito, sugerimos que este possa ser formada pela degradação do tocoferol e filoquinona. Parte dessa molécula poderia estar ligada a ácidos graxos sendo utilizada como constituinte de membrana, e a outra parte sofreria duas fosforilações, gerando posteriormente as vitaminas E e K1 como uma segunda via de biossíntese desses compostos, assim como ocorre em Arabidopsis thaliana. Por marcações metabólicas com $\left[{ }^{3} \mathrm{H}\right]$ GGPP e análise por HPLC e TLC confirmamos a presença de fitol nos estágios intraeritrocíticos do parasito. Para caracterizar a atividade fitol quinase, utilizamos $\left[{ }^{3} \mathrm{H}\right]$-Fitol como substrato e os NTPs: ATP, CTP, UTP e GTP como doador de fosfato, mostrando que o fitol é convertido para fitil-P e fitil-PP, sendo posteriormente empregado para síntese de vitamina $\mathrm{E}$ e $\mathrm{K} 1$. Esses resultados ajudam a compreender mais a biologia de $P$. falciparum, bem como, confirmar a presença de filoquinona e vitamina $\mathrm{E}$ no parasito.

Palavras-chave: Malária. Plasmodium falciparum. Malária. Fitol. Vitamina E e K1 


\begin{abstract}
Vega DSM. Characterization of phyto and an alternative pathway for phylloquinone and tocopherol biosynthesis in intraerythrocytic stages of Plasmodium falciparum [Masters thesis (Parasitology)]. São Paulo: Instituto de Ciências Biomédicas, Universidade de São Paulo; 2013.

Our group identified products of isoprenoids pathway in Plasmodium. falciparum. This pathway is could be as promising new target of antimalarial drugs since this pathway is not shared by the human host. The isoprenoids compounds identified in intraerythrocytic forms of $P$. falciparum, were isoprenicd chains attach to proteins (protein isoprenylation), and ring benzoquinone (Coenzyme $Q$ 7-9), besides carotenoids, dolichois (11 and 12 isoprene units) menaquinone, phylloquinone and tocopherol. Vitamins $\mathrm{K} 1$ and $\mathrm{E}$ have an isoprenic phytyl side chain. In plants the phytol is obtained from the chlorophyll degradation. Until now there's no evidence that support its presence in the parasite. We hypothesize that phytol can be produced by the degradation of these vitamins $\mathrm{E}$ and $\mathrm{K} 1$. In the parasite phytol would fulfill to functions: used as a constituent of membrane bounded to fatty acids and; be converted through phosphorylations vitamins $\mathrm{E}$ and $\mathrm{K} 1$ as a second biosynthetic pathway as well as in Arabidopsis thaliana. Analyses through and HPLC and TLC with radioactive labeling $\left[{ }^{3} \mathrm{H}\right]$-GGPP confirmed the presence of phytol in intraerythrocytic stages of the parasite. In addition, we showed that $\left[{ }^{3} \mathrm{H}\right]$-phytol is converted into phytyl-P and phytyl-PP through a phytol kinase using nucleotides as phosphate donor ATP , CTP , UTP and GTP, showing that the phytol, is converted to phytyl-P and phytyl-PP and subsequently used for synthesis of vitamin $E$ and $\mathrm{K} 1$. These results corroborate to further understand the biology of $P$. falciparum, as well as confirm the presence of phylloquinone and vitamin $E$ in parasite.
\end{abstract}

Keywords: Malaria. Plasmodium falciparum. Malaria. Phytol. Vitamin E and K1. 


\begin{tabular}{|c|c|}
\hline$\mu \mathrm{Ci}$ & MicroCurie \\
\hline $\mathrm{ACN}$ & Acetonitrila \\
\hline AIDS & Sindrome da imunodeficiência adquirida \\
\hline ATP & Adenina trifosfato \\
\hline BHT & Hidroxitolueno butilado \\
\hline $\mathrm{Ca}^{2+}$ & Cálcio \\
\hline CTP & Citidina trifosfato \\
\hline DMAPP & Dimetilalil pirofosfato \\
\hline DOX & 1-deoxi-D-xilulose \\
\hline DOXP & 1-deoxi-D-xilulose 5-fosfato \\
\hline DTT & Dicloro-difenil-tricloroetano \\
\hline EDTA & Ácido etilenodiamino tetra-acético \\
\hline EPSP sintase & 5'-enolpiruvil-chiquimato3-fosfato-sintase \\
\hline ERNs & Espécies reativas de nitrogênio \\
\hline EROs & Espécies reativas de oxigênios \\
\hline Fe(III)PPIX & Ferritroporfirina \\
\hline FPP & Pirofosfato de farnesila \\
\hline GGPP & Pirofosfato de geranilgeranila \\
\hline GTP & Guanidina trifosfato \\
\hline $\mathrm{H}_{2} \mathrm{O}$ & Água \\
\hline HPLC & High Performance Liquid Cromatography \\
\hline IPP & Isopentenil pirofosfato \\
\hline $\mathrm{KCl}$ & Cloreto de potássio \\
\hline $\mathrm{KH}_{2} \mathrm{PO}_{4}$ & Fosfato de potássio monobásico \\
\hline LSD & Drogas alucinógenas \\
\hline MACS & Separation columns - 25 CS columns \\
\hline $\mathrm{MeOH}$ & Metanol \\
\hline MEP & $2 C$-metil-D-eritritol 4-fosfato \\
\hline MFS & Filtro de nylon \\
\hline $\mathrm{MgCl}_{2}$ & Cloreto de magnésio \\
\hline $\mathrm{Na}_{2} \mathrm{HPO}_{4}$ & Fosfato de sódio monobásico \\
\hline $\mathrm{NaCl}_{2}$ & Cloreto de sódio \\
\hline $\mathrm{NaF}$ & Fluoreto de sódio \\
\hline
\end{tabular}




$\begin{array}{ll}\mathrm{NaHCO}_{3} & \text { Bicarbonato de sódio } \\ \mathrm{NH}_{4} \mathrm{OH} & \text { Hidroxido de amônio } \\ \mathrm{NTPs} & \text { Nucleodeos } \\ \text { pABA } & \text { p-aminobenzeno } \\ \text { PBS } & \text { Phosphate Buffer Saline } \\ \text { PQs } & \text { Proteínas quinase } \\ \text { PTFE } & \text { Phenes filter membranes } \\ \text { TLC } & \text { Thin later chromatography } \\ \text { UTP } & \text { Uracila trifosfato }\end{array}$




\section{LISTA DE ILUSTRAÇÕES}

Figura 1. Ciclo de vida de Plasmodium falciparum........................................ 20

Figura 2. Via MEP Isoprenóide................................................................ 24

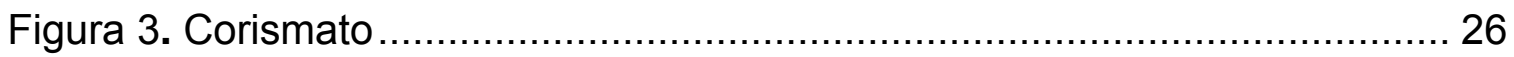

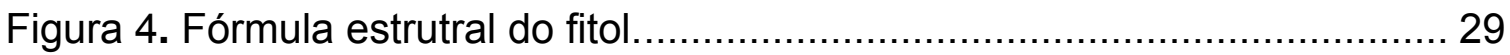

Figura 5. Metabolismo do Fitol em Arabidopsis................................................. 30

Figura 6. Perfil de eluição radioativa de esquizontes .................................... 46

Figura 7.Perfil de eluição radioativa nas formas intraeritrocíticas ..................... 47

Figura 8. Perfil de eluição radioativa recromatografia .................................... 49

Figura 9. Perfil de eluição radioativa de esquizontes ...................................... 50

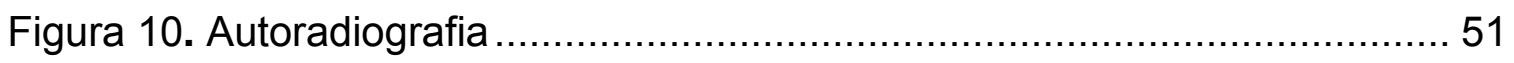

Figura 11. A e B Perfil de eluição radioativa do ensaio de fosforilação do fitol .. 52

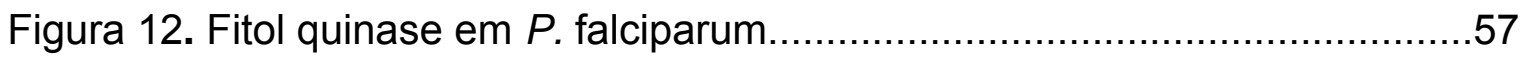




\section{LISTA DE TABELAS}

Tabela 1 Valores dos $R_{f}$ de produtos da via de isoprenóides cromatografadas em TLC para análise de fitol utilizando como solvente: Isopropanol//NH4OH/H2O (6:3:1) 


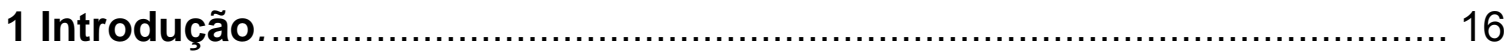

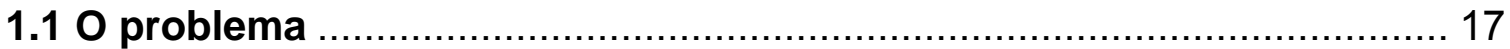

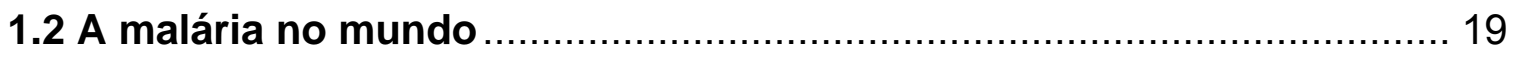

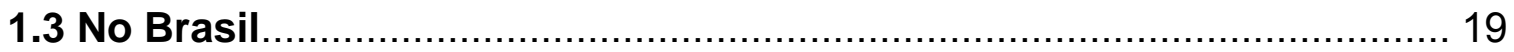

1.4 Ciclo de vida do Plasmodium em humanos ..................................... 19

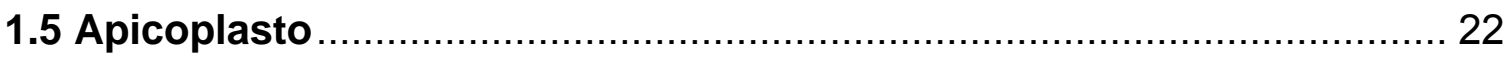

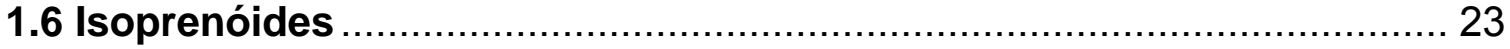

1.7 Via do Metil eritritol fosfato- MEP-Isoprenóides .............................. 23

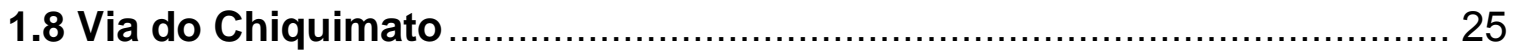

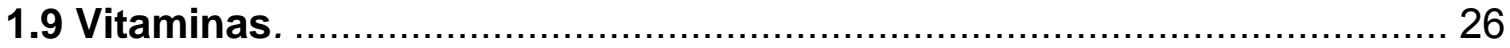

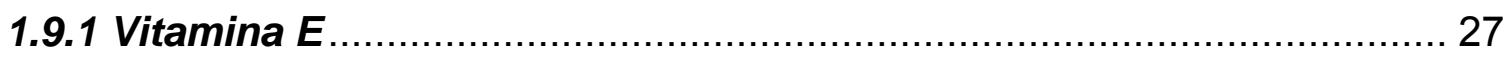

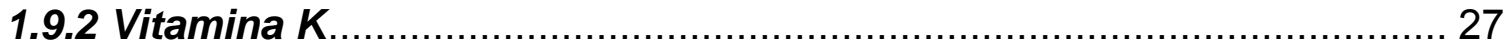

1.10 A Importância de estudar fitol no parasito........................................ 31

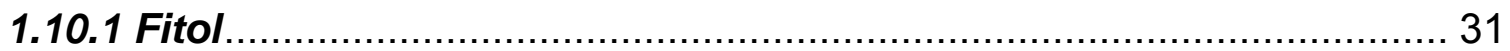

1.110 papel das proteínas quinase em Plasmodium falciparum .............. 31

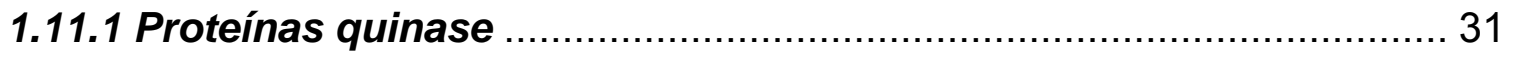

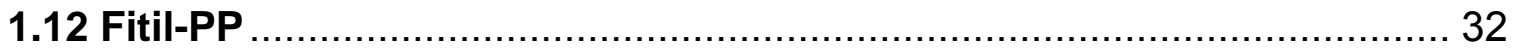

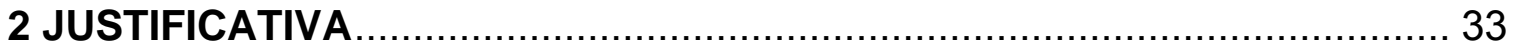

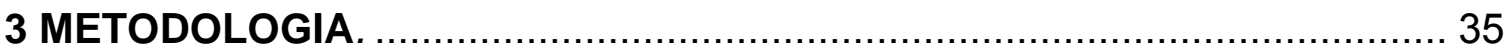

3.1 Cultura de Plasmodium falciparum ............................................... 36

3.2 Sincronização de parasitos por Plasmagel................................... 36

3.3 Sincronização de parasitos por Sorbitol ............................................. 36

3.4 Separação e purificação dos estágios intraeritrocíticos ..................... 37

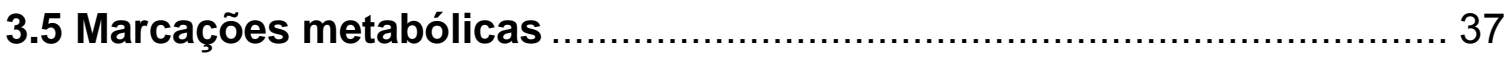

3.6 Sistemas de cromatografia para caracterização de Fitol e Fitil-PP ....... 38

3.6.1 Cromatografia líquida de alta eficiência - HPLC ............................ 39

3.6.2 Cromatografia de camada delgada - TLC ................................ 39 
3.7 Cuidados no processamento de fitol e fitil-PP ................................. 39

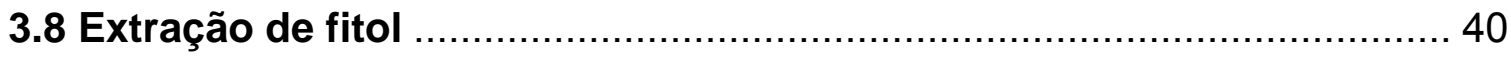

3.8.1 Análise por cromatografia líquida de alta performance - HPLC ......... 40

3.8.2 Cromatografia e recromatografia por HPLC para identificação de fitol

3.9 Extração de Fitil-PP ....................................................................... 42

3.9.1 Análise de Fitil-PP por HPLC .................................................. 42

3.10 Ensaios de fosforilação do fitol ................................................ 43

3.10.1 Análise da Atividade de fitol quinase por HPLC ............................ 43

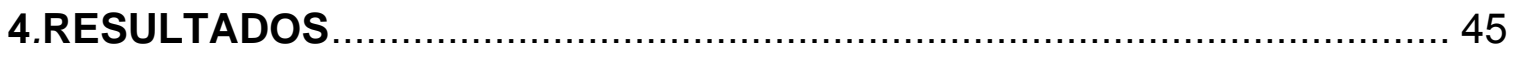

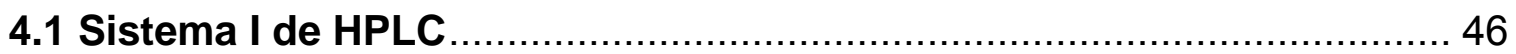

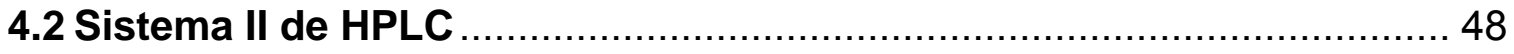

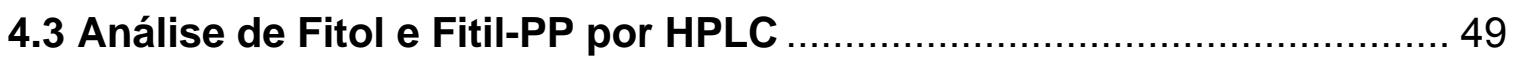

1.4 Análise de fitol por cromatografia TLC ....................................... 50

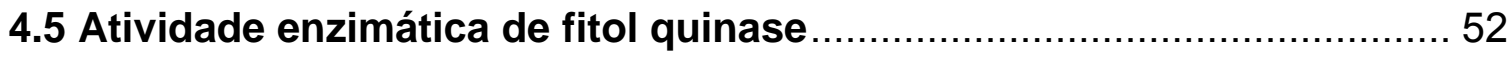

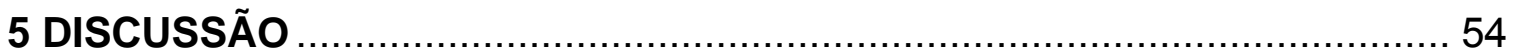

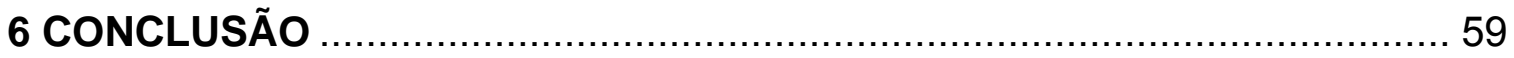

REFERÊNCIA 
1 INTRODUÇÃO 



\subsection{O problema}

A malaria é uma doença infecciosa causada por um protozoário unicelular do gênero Plasmodium e pode ser transmitida ao ser humano pela picada do mosquito do gênero Anopheles (1).

Estimam-se em 400 milhões os casos de incidência de malária no mundo, com o registro de um milhão de óbitos por ano, sendo a maioria dos casos ocorridos em países de clima tropical como África, Ásia e nas Américas, onde cinco são as espécies que infectam o homem: $P$. falciparum, $P$. vivax, $P$. malariae, $P$. ovale e $P$. knowlesi (1-4).

O desafio atual é usar os antimaláricos existentes de forma mais eficiente para melhorar o controle da doença. Isto significa que se deve aprimorar o acesso às drogas apropriadas e suas combinações, fornecendo medicamentos com custos baixos, vigilância crescente a fim de orientar o uso adequado das drogas e mais atenção para estratégias alternativas de prevenção, como uso de mosquiteiros tratados com inseticidas por exemplo (5).

Nos últimos anos, além de observar o surgimento de parasitos resistentes às drogas observaram-se vetores resistentes aos inseticidas. Isso se deve à administração indevida de antimaláricos e inseticidas, aos movimentos populacionais em massa, aos serviços de saúde inadequados, bem como os recursos financeiros limitados, a falta e dificuldades operacionais na implementação de medidas para o controle da doença (5). Esses fatores colaboram para o aumento do número de casos de morbidade e mortalidade ocasionados pela doença. Essa resistência pelo $P$. falciparum e $P$.vivax às drogas antimaláricas utilizadas na terapêutica levam a necessidade do desenvolvimento de novas terapias antimaláricas (6).

A resistência às drogas tem sido um dos obstáculos encontrados no combate a doença, como foi observada em 1967, em um programa de erradicação da doença, a resistência à cloroquina na maioria das regiões onde o $P$. falciparum era endêmico além da resistência de outros antimaláricos habitualmente utilizados hoje em dia como sulfadoxina, pirimetamina e mefloquina (5).

Os alvos biológicos que visam o desenvolvimento de novas terapias para o tratamento da malária abrangem funções celulares, tais como: detoxificação do 
heme ou ferriprotoporfirina IX (Fe(III)PPIX) (7), metabolismo redox e mecanismos de defesa antioxidante que possam gerar um estresse oxidativo no parasito (8-10) e o metabolismo do folato, já explorados para drogas estabelecidas como antimaláricos, assim como novas vias metabólicas, tais como síntese de ácidos graxos, e biossíntese de isoprenóides (11).

\subsection{A malária no mundo}

No cenário atual, há um predomínio da malária em regiões tropicais que é intensificado pelo problema da resistência aos antimaláricos e inseticidas utilizados indiscriminadamente.

Há uma tendência no aumento da malária em regiões endêmicas, sendo um grande problema de saúde em regiões da América do Sul, Ásia e principalmente África Subsaariana. Na África Subsaariana, a malária também representa um problema econômico, por diminuir o período ativo do trabalhador, requerendo um maior investimento do governo na área de saúde, além de reduzir o contingente de trabalhadores, já que muitos desses ficam com sequelas devido à doença. Normalmente, a maioria dos casos é registrada em gestantes e crianças de até cinco anos (12). Em mulheres grávidas quando acometidas pela malária perdem peso, podem sofrer abortos espontâneos e morrer em decorrência da doença. Isso ocorre porque a placenta é um local de sequestro de $P$. falciparum, o que parece ser um local privilegiado para a multiplicação do parasito, além da diminuição da imunidade adquirida pelos adultos durante a gestação. No caso de crianças de até cinco anos a alta taxa de mortalidade está relacionada com o lento desenvolvimento da imunidade $(6,13)$.

Na Europa Oriental e Ásia central onde a malária já havia sido erradicada a doença reincidiu e hoje mata mais pessoas do que há 30 anos (12).

A instabilidade climática, assim como os problemas no tratamento pelos deslocamentos de contingentes em consequência de guerras civis, a AIDS e a resistências aos antimaláricos utilizados é agravante na situação da malária no mundo (13), outro fator agravante é o aumento da resistência aos antimaláricos (13, 14). 


\subsection{No Brasil}

No Brasil, às mudanças sócio econômicas ocorridas partir da década de 50 , quando teve inicio a implantação de projetos de desenvolvimento da Amazônia, levaram a uma migração interna em direção à região norte do país aumentando à exposição de muitas pessoas a áreas endêmicas de malária, assim como, alterações ambientais. Dentro dessas alterações destacam-se: projetos de assentamentos agropecuários, construção de hidroelétricas, extrativismos vegetal e mineral, os quais têm provocado desmatamento de áreas extensas, agressões ao ambiente, desorganização espacial e concentração de pessoas em condições sanitárias inadequadas (15). Outro fator determinante para o aumento no número de casos de malária foi o surgimento e propagação de parasitos resistentes à maior parte dos antimaláricos disponíveis, tornando-se um grave problema de saúde pública.

A malária é transmitida pela picada de mosquitos fêmeas do gênero Anopheles. As fêmeas por sua vez são hematófagas, portanto, as responsáveis pela transmissão da doença para os humanos. O gênero Anopheles inclui aproximadamente 400 espécies no mundo, mas apenas 60 são capazes de transmitir o parasito em condições naturais (16).

\subsection{Ciclo de vida do Plasmodium em humanos}

O ciclo biológico do Plasmodium que infecta os seres humanos é muito semelhante entre as espécies e apresenta basicamente duas fases (Figura 1)

$\checkmark$ Ciclo de vida do vertebrado: Nesta etapa do ciclo de vida do parasito ocorre sua reprodução assexuada, também conhecida como esquizogonia. Esse ciclo pode ser dividido em duas fases: hepática e ciclo intraeritrocítico (17).

Mosquitos infectados ao picarem o homem sadio, injetam uma pequena quantidade de saliva, que serve como anticoagulante e anestésico, na qual se encontram esporozoítos. Com a finalidade de tentar localizar o capilar sanguíneo, o mosquito realiza um movimento chamado de probe, onde com seu aparelho bucal, faz incursões por toda região da picada, sempre injetando pequenas quantidades de saliva. Desta maneira, os esporozoítos podem ser lançados nos vasos sanguíneos 
ou tecidos adjacentes a estes. Os esporozoítos lançados nos arredores dos capilares sanguíneos começam realizar movimentos circulares chamados gliding, (18) que possibilita que eles adentrem aos capilares sanguíneos e, possivelmente, aos capilares do sistema linfático (17).

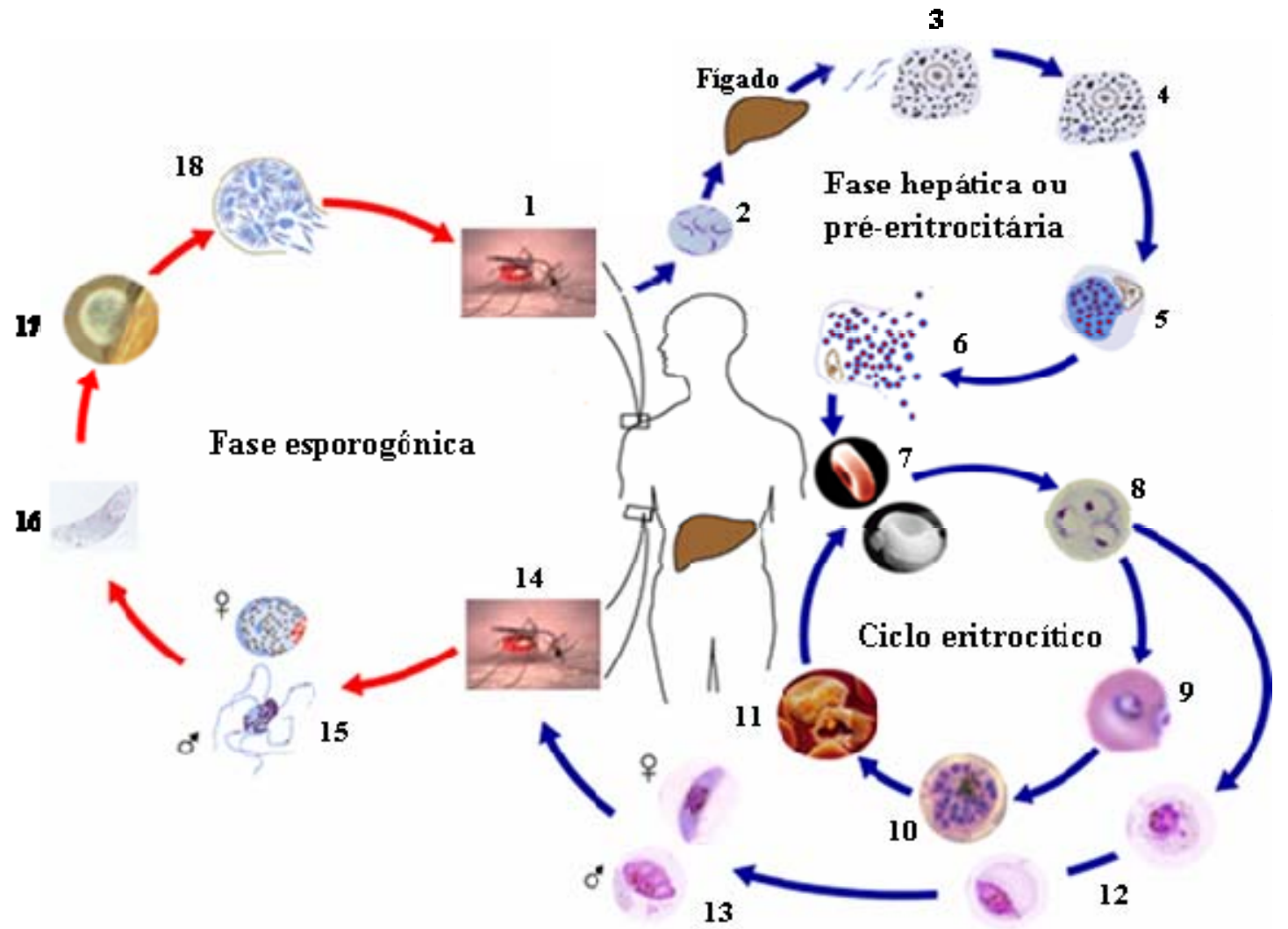

Figura 1. Ciclo de vida de Plasmodium falciparum. Durante a alimentação, a fêmea infectada do mosquito Anopheles inocula os esporozoítos no hospedeiro humano (1). Os esporozoítos (2) podem então infectar as células hepáticas. Ao invadirem os hepatócitos (3), os esporozoítos transformam-se em criptozoítas (4) e após sofrer uma esquizogonia eles se transformam em esquizontes hepáticos (5). Com a ruptura dos esquizontes hepáticos (6), os merozoítos são liberados na corrente sangüínea e invadem os eritrócitos (7). Após a invasão, os merozoítos começam a se desenvolver nos estágio anel (8), trofozoíta maduro (9) e esquizonte (10), culminando com a ruptura da hemácia e liberação de novos merozoítos, que darão continuidade ao ciclo eritrocítico. Alguns parasitos na forma anel se diferenciam em gametas (12), formando os gametócitos masculino e feminino (13). Ao serem ingurgitados pela fêmea do mosquito (14) durante a alimentação, os gametócitos masculino e feminino se diferenciam no estômago do inseto em microgameta e macrogameta, respectivamente (15). O macrogameta é fecundado pelo microgameta, gerando o zigoto ou oocineto (16) o qual migra para a membrana basal do epitélio estomacal do inseto. O oocineto então se transforma em oocisto (17). O oocisto sofre uma multiplicação esporogônica, gerando milhares de esporozoítos, que, após a ruptura do oocisto (18), irão se dirigir às glândulas salivares do inseto. Modificado de www.cdc.org.

Após 15-45 min, os esporozoítos que atingiram a corrente sanguínea, alcançam o fígado e invadem as células hepáticas.

Dentro do hepatócito, os esporozoítos transformam-se em células arredondadas chamadas criptozoítas, originando à fase hepática da doença, dificultando a detecção do parasito nessa fase. No hepatócito, os merozoítos passam por uma divisão assexuada chamada esquizogonia tecidual e passaram a ser chamados de esquizontes hepáticos. A esquizogonia hepática dura seis dias no 
caso de $P$. falciparum, oito dias no de $P$. vivax, nove dias para $P$. ovale e de 12 a 16 dias para $P$. malariae (17).

Os esquizontes hepáticos, quando maduros, rompem o hepatócito, liberando os merozoítos diretamente nos capilares sanguíneos do fígado. Muitos dos merozoítos liberados são fagocitados e destruídos pelas células de Kupffer, mas os que sobrevivem invadem os glóbulos vermelhos do sangue, dando início ao ciclo intraeritrocítico.

No interior das hemácias os merozoítos iniciam o seu desenvolvimento passando pelas formas de trofozoíto jovem, trofozoíto maduro e esquizonte. $\mathrm{Na}$ forma esquizonte, ocorre mais um evento de esquizogonia, dando origem a um determinado número de merozoítos por cada esquizonte, sendo este característico para cada espécie de Plasmodium. Nas infecções causadas por $P$. falciparum, somente nos casos de infecções graves são observados trofozoítos maduros e esquizontes no sangue periférico, devido à citoaderência dessas formas à paredes dos capilares profundos, fato este que causa a severidade desse tipo de malária (17).

Como há uma sincronia no desenvolvimento dos parasitos, o rompimento das hemácias infectadas com a liberação dos merozoítos na corrente sanguínea ocorre ao mesmo tempo, fato que culmina com os acessos de febre. Esses ciclos são extremamente regulares e característicos de cada espécie de plasmodium.

Depois de algum tempo e por fatores ainda desconhecidos, os trofozoítos jovens diferenciam-se em gametócitos masculino ou feminino. Os gametócitos não sofrem mais nenhuma divisão, sendo encontrados no sangue periférico. Sua vida média pode ser de 60 dias (17).

Ciclo no hospedeiro invertebrado: Os anofelinos, machos e fêmeas alimentam-se de néctar e seiva vegetal, mas as fêmeas necessitam de sangue em sua dieta alimentar para o amadurecimento de seus ovos, e consequentemente, para possibilitar a ovoposição (17).

Após uma fêmea do mosquito Anopheles ingerir sangue de uma pessoa infectada contendo as formas sexuadas do parasito, gametócitos feminino e masculino, inicia-se uma fase sexuada dentro de seu trato digestivo. Gametas femininos e masculinos diferenciam-se em macrogameta e microgameta, 
respectivamente. Após a fecundação do macrogameta pelo microgameta, ocorre a formação do zigoto ou oocineto, poucos minutos após a ingestão do sangue. $O$ zigoto é a única fase diplóide no ciclo de vida do parasito. O zigoto, portanto, migrará pela camada única de células da parede do estômago do mosquito, alojando-se entre essas células e a membrana basal do epitélio. O oocineto se transforma em oocisto desenvolvendo uma grossa cápsula, a qual permite a passagem de nutrientes para a geração dos esporozoítos. O oocineto se rompe e libera os esporozoítos que alcançam a hemolinfa do inseto e migram para as glândulas salivares. No momento da picada, os esporozoítos poderão ser inoculados no hospedeiro vertebrado e, assim, dar seguimento ao ciclo do parasito (17).

A existência de reprodução sexuada pelo Plasmodium possibilita a recombinação gênica $e$, com isso, o surgimento de novas cepas resistentes às drogas usadas para o controle da doença (17). Por isso, a importância em estudar a biologia e novas vias metabólicas, por exemplo, as encontradas no apicoplasto, organela presente no parasito.

\subsection{Apicoplasto}

O plasmodium é um protozoário que pertence ao filo apicomplexa, os quais apresentam uma organela denominada apicoplasto. Sugere-se que essa organela seja resultante de uma endossimbiose secundária, assim, como o cloroplasto em plantas. Uma alga fotossintetizante, possuindo um plastídio originado de uma endossimbiose primária, teria sido englobada por um organismo não fotossintetizante, dando origem a uma endossimbiose secundária, o que justificaria as várias membranas observadas nos apicoplastos, geralmente 3 ou 4 . As duas membranas internas corresponderiam ao plastídio presente na alga englobada, já a terceira, seria à membrana da alga. A última e mais externa seria derivada do sistema endomembranar do hospedeiro. Em alguns casos, teria ocorrido a perda de uma dessas membranas, restando apenas 3. Ainda resta a discussão se essa alga seria um ancestral das algas vermelhas ou das verdes. (19)

Waller et al. (1998), ao inibir o crescimento de $P$. falciparum, obervou-se que o apicoplasto possui um papel essencial na biossíntese de ácidos graxos (20). 
O plasmodium reteve algumas vias biossintéticas localizadas no apicoplasto, como a biossíntese de isoprenóides, de ácidos graxos e potencialmente do heme. As enzimas dessas vias são codificadas no núcleo e apresentam peptídeos que sinalizam sua sub-localização no apicoplasto e peptídeos de transito pelo sistema de membrana localizados na porção $\mathrm{N}$-terminal (21). Por isso a importância de estudar a caracterização dos produtos da biossíntese de isoprenóides em plasmodium, especificamente em $P$. falciparum, $(22,23)$.

\subsection{Isoprenóides}

Os isoprenópides, portanto, prenóis constituem a mais divergente e grande família de compostos naturais, estando presente em todos os organismos vivos. São conhecidos mais de 30.000 compostos isoprênicos na natureza, sendo metabólitos essenciais para diversas funções celulares, incluindo compostos como ubiquinonas, dolicóis, compostos isoprênicos ligados às proteínas e RNA, hormônios em animais e plantas, carotenóides, vitaminas e óleos essenciais (24).

O conjunto dos compostos isoprênicos é biossintetizado formado a partir de dois precursores, os quais são as unidades básicas dos isoprenóides: isopentenil pirofosfato (IPP) e seu isômero dimetilalil (DMAPP) $(25,26)$

\subsection{Via do metil eritritol fosfato - MEP Isoprenóides}

As unidades básicas IPP e seu isomero DMAPP podem ser biossintetizadas pela via do Mevalonato e pela via do 2C-metil-D-eritritol-4-fosfato (MEP). Os animais possuem a via do mevalonato, as bactérias utilizam a via 1-deoxi-D-xilose 5fosfato/2C-metil-D-eritritol-4-fosfato DOXP/MEP e as plantas superiores possuem essa última via no plastídio e a via do mevalonato no citoplasma. A via DOXP/MEP, foi originalmente chamada de via de Rohmer ou via independente do mevalonato. Após a identificação do primeiro passo da via, o nome foi trocado para indicar os substratos (via do piruvato/gliceraldeído-3-fosfato - GAP) ou o primeiro intermediário da via, 1-deoxi-D-xilulose 5-fosfato (via DOXP). Entretanto, o nome mais aceito é via do 2C-metil-D-eritritol-4-fosfato (MEP) (27) o primeiro precursor exclusivo da via seguindo a mesma regra usada para nomear a via Mevalonato. A identificação do 
pirofosfato de farnesila (FPP) (28), assim como a presença de dolicóis (23) e proteínas covalentemente modificadas por isoprenóides (29), foram às primeiras evidências para o estudo da biossíntese de isoprenóides em $P$. falciparum. A caracterização de dois genes essências da via MEP (DOXP sintase e redutoisomerase) foi descrita por Jomaa et al. (1999) (30), bem como, a demonstração de que o parasito utiliza a via MEP (Figura 2) para a biossíntese de isoprenóides. Cassera et al. (2004) descreveu os intermediários da via MEP (Figura 2), além da biossíntese do novo da piridoxina 5' P (31).

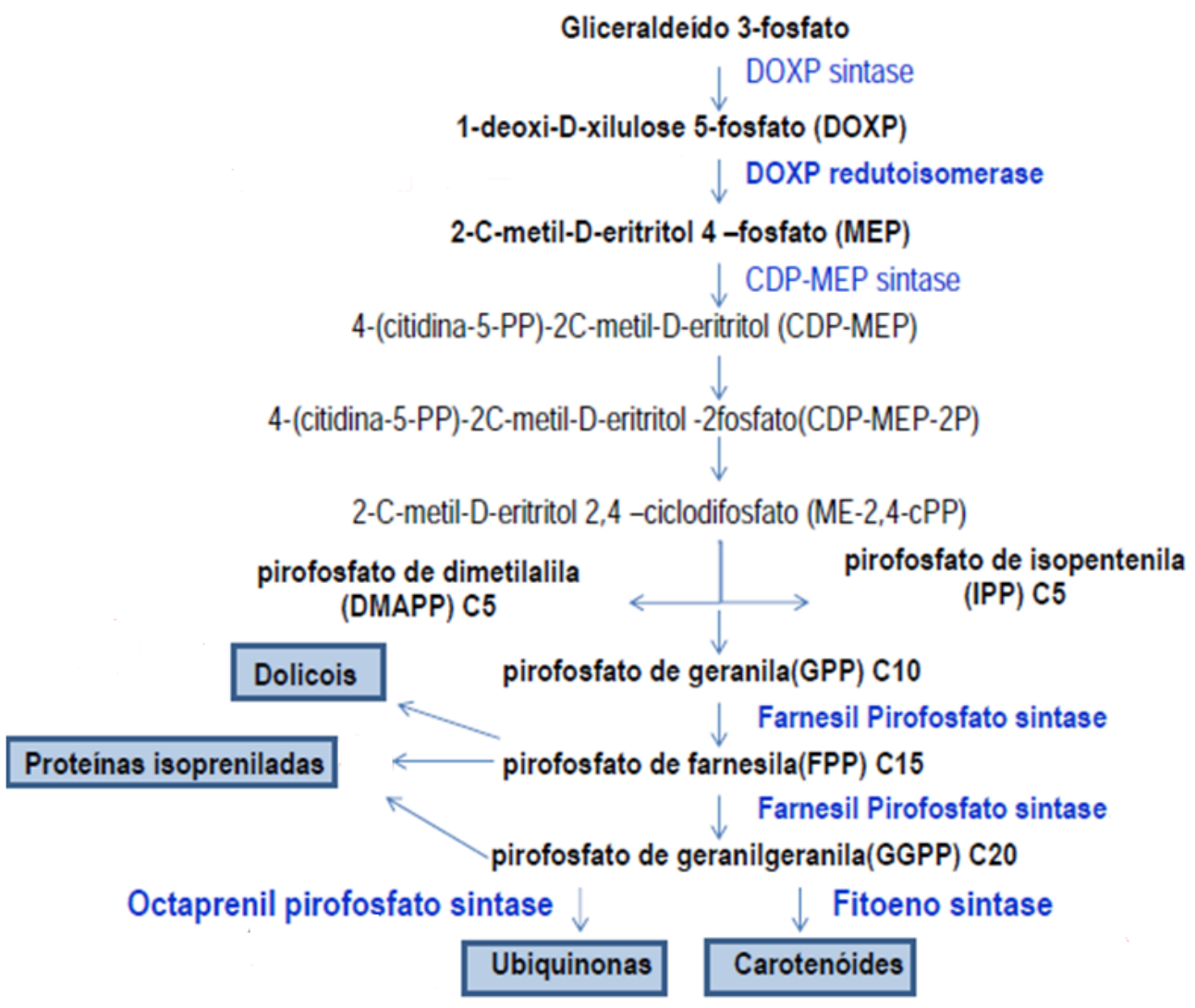

Figura 2. Via MEP Isoprenóide, onde o IPP e o DMAPP são precursores para a síntese de isoprenóídes lineares (GPP, FPP e GGPP), que são intermediários para biossíntese de diferentes produtos tais como: dolicóis de 11/12 unidades isoprênicas e seus derivados fosforilados, cadeias isoprênicas ligadas ao anel benzoquinona coenzima $Q$ de 8 e 9 unidades, menaquinona, proteínas isoprenicas e carotenóides

Os produtos finais da biossíntese de isoprenóides descritos em $P$. falciparum são dolicóis de 11 e 12 unidades isoprênicas, coenzimas Q7-8-9, proteínas isopreniladas e doliquiladas, carotenóides e as vitaminas E e K (23, 32-35)

Em plantas um dos produtos finais da via de isoprenóides são os terpenos, que possuem atividade bactericida $(36,37)$. Goulart et al. (2004) demonstraram o 
efeito de quatro terpenos e um derivado sintético sobre o desenvolvimento in vitro do parasito e também o efeito destes sobre a biossíntese de isoprenóides (38).

Esta via metabólica, assim como a via do Chiquimato não é compartilhada pelo hospedeiro humano, fazendo com que se torne um excelente alvo para o desenvolvimento de antimaláricos uma vez que a droga afetaria apenas a via do parasito $(27,39)$.

\subsection{Via do chiquimato}

A via do Chiquimato (Figura 3) é outra via encontrada no apicoplasto de $P$. falciparum, e tem como produtos finais os aminoácidos aromáticos: fenilalanina, tirosina e triptofano, e como intermediário o corismato. São sete passos até a formação do corismato, iniciando com a condensação de fosfoenolpiruvato e eritrose 4-fosfato. Seus intermediários são pontos de ramificação para diversas outras vias. Além dos aminoácidos aromáticos, o corismato pode originar diversos outros compostos aromáticos, como: tetraidrofolato, o anel hidroxibenzoato origina as ubiquinona, o anel homogentisato que faz parte da biossíntese de vitamina $\mathrm{E}$ e o anel isocorismato que faz parte das vitaminas $\mathrm{K}(40)$.

Sabe-se que a via do chiquimato é conhecida em algas, plantas superiores, bactérias e fungos, mas esta, também se encontra presente em parasitos do filo apicomplexa. Em $P$. faciparum a via foi descoberta como parte da biossíntese de folatos (41).

A inibição do crescimento in vitro de Toxoplasma gondii, Plasmodium falciparum e Cryptosporidium parvum, utilizando o glifosato que atua sobre a enzima 5-enolpiruvil-chiquimato3-fosfato-sintase (EPSP sintase) da via do chiquimato foi demonstrada por Roberts et al. (1998). Em T. gonddi e P. falciparum, o efeito foi revertido pela adição do p-aminobenzoato (pABA), um dos intermediários da via do chiquimato na biossíntese de folatos (42).

Por ser uma via metabólica encontrada em plantas e microorganismos como Mycobacterium turberculosis e $P$. falciparum e ausente em mamíferos, considera-se um alvo importante para o desenvolvimento de herbicidas, vacinas e outras drogas. 
Via do Chiquimato

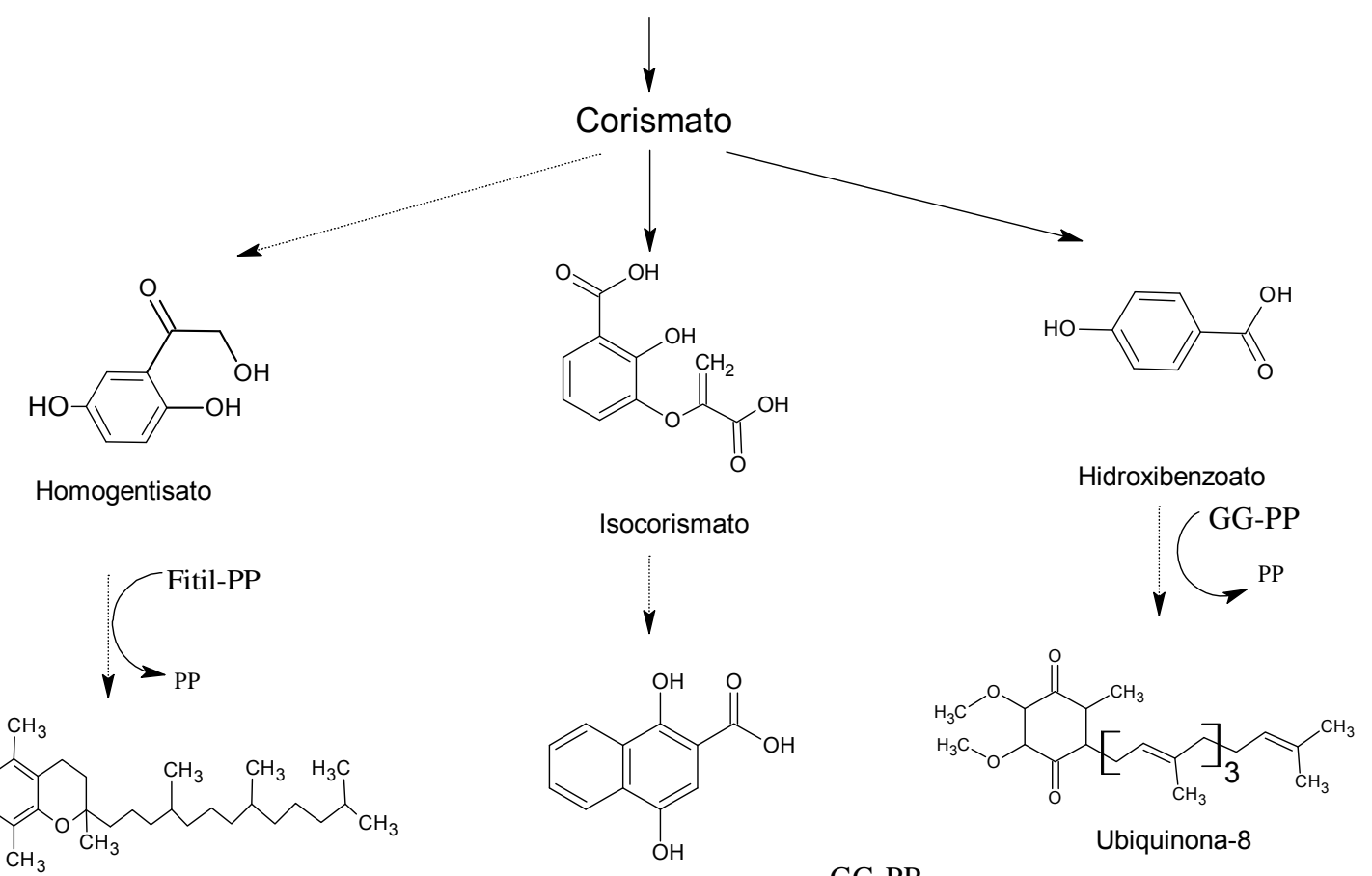

$\alpha$-Tocoferol

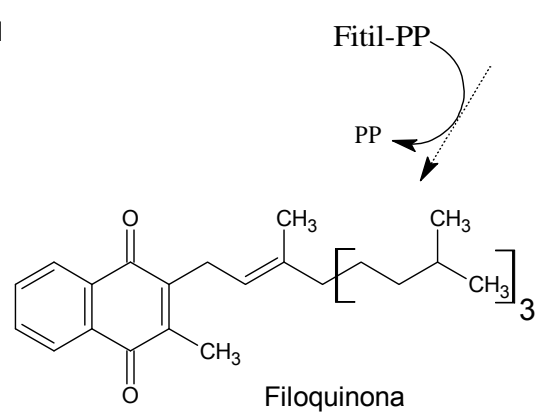

GG-PP

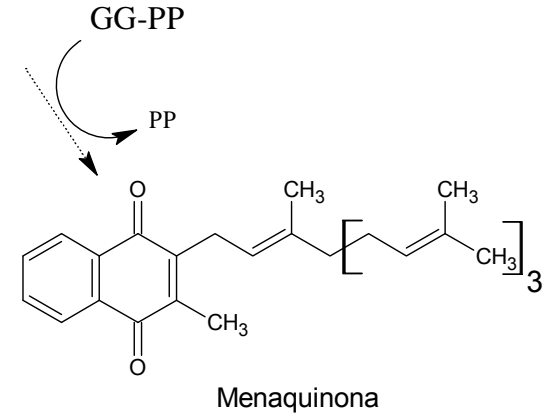

Figura 3. Corismato (proveniente da via do chiquimato) origina diversos produtos aromáticos como ubiquinona, vitaminas E e K. A vitamina E (tocoferol) possui uma cadeia isoprênica denominada fitil pirofosfato, proveniente da via MEP e o anel de cromanol é proveniente da via do Chiquimato, tendo o homogentisato como precursor. As vitaminas $\mathrm{K}$ têm como precursor o isocorismato. A vitamina $\mathrm{K}_{1}$ ou filoquinona possui cadeia lateral com 4 unidades isoprênicas e insaturação apenas na primeira unidade. Já a vitamina $\mathrm{K}_{2}$ menaquinona, possui cadeia lateral com número variável de unidades isoprênicas (n), todas com uma insaturação. A Ubiquinona tem como precursor o anel hidroxibenzoato. Os anéis são isoprenilados por um GGPP e posteirormente metilado.

\subsection{Vitaminas}

As vitaminas são divididas em lipossolúveis e hidrossolúveis, elas são essenciais à atividade biológica, sendo requerida em pequenas quantidades. As vitaminas lipossolúveis geralmente fazem parte da membrana celular, agindo de forma semelhante aos hormônios esteroides, e as hidrossolúveis são cofatores enzimáticos. Entre as vitaminas lipossolúveis encontramos as vitaminas $A, E$ e $\mathrm{K}$, 
que apresentam cadeia isoprênica em sua constituição, provenientes da via MEP, sendo que as vitaminas $\mathrm{E}$ e $\mathrm{K}$ também possuem anéis aromáticos, que são oriundos da via do Chiquimato (43).

\subsubsection{Vitamina $E$}

O grupo dos tocoferóis e tocotrienóis (vitamina E) compreendem oito compostos lipossolúveis formados por um anel de cromanol ligado à cadeia isoprênica. A diferenciação destes compostos consiste no número e posição dos grupos metila do anel e as insaturações da cadeia isoprênica (44).

O a-tocoferol é a forma que apresenta maior bioatividade e sua principal função é a de proteção das membranas contra a lipoperoxidação $(44,45)$. Ele apresenta uma cadeia denominada fitil-PP que é um precursor ativo da biossíntese de diferentes lipídeos isoprênicos que é proveniente da via MEP onde o anel cromanol é oriundo da via do Chiquimato (44).

Compostos conhecidos como vitamina $E$, são potentes antioxidantes e protegem os ácidos graxos poliinsaturados da peroxidação lipídica. Essa atividade resulta capacidade de reagir diretamente com compostos reativos, como radicais livres lipídicos, espécies reativas de oxigênio (EROs) e também, espécies reativas de nitrogênio (ERNs). No entanto a principal função da vitamina $E$ é evitar a autooxidação de ácidos graxos poliinsaturados $(46,47)$

Sussmann et al. (2011), verificou a biossíntese de tocoferol em $P$. falciparum e concluiu que o a-tocoferol atua como agente lipofílico, protegendo a membrana da lipoperoxidação nos três estágios intraeritrocíticos de $P$. falciparum(48).

\subsubsection{Vitamina $K$}

Em plantas e cianobactérias a filoquinona (vitamina K1) participa na transferência de elétrons do fotossistema I $(49,50)$. Já a menaquinona (vitamina $\mathrm{K} 2$ ), presente em bactérias, também atua na transferência de elétrons, mas na cadeia respiratória de bactérias anaeróbias, em alguns casos, atua reduzindo o fumarato (50). 
Nosso grupo de pesquisa descreveu a biossíntese de menaquinona, mostrando que ela participa como transportadora de elétrons em $P$. falciparum (35).

A presença de filoquinona em $P$. falciparum foi identificada preliminarmente pela aluna Miriam Matsumura, durante o desenvolvimento do seu projeto de mestrado que tinha como um dos objetivos a caracterização de vitamina K. Heloísa Gabriel deu continuidade a este trabalho, e em sua dissertação identificou filoquinona no parasito sugerindo quer ela tem ação antioxidante (51). Rodrigo Sussmann confirmou a presença de filoquinona no parasito, bem como sua função (dados não publicados).

\subsection{A importância de estudar fitol no parasito}

A cadeia hidrofóbica de filoquinona e tocoferol é um 3-fitil, sendo importante estudar a presença deste isoprenóide. Além de conhecer mais sobre a biologia do parasito, poderemos buscar o desenvolvimento de um novo antimalárico. Outro ponto importante seria demonstrar a presença de fitol e elucidar uma reciclagem dessa molécula para a biossíntese das vitaminas E e K1 em $P$. falciparum e a regulação das etapas enzimáticas envolvidas na sua formação, bem como verificar se o fitol originado da degradação da vitamina E e K1 no parasito, e confirmar a presença de filoquinona no parasito.

\subsubsection{Fitol}

O fitol é um diterpeno que pertence ao grupo dos álcoois acíclicos insaturados de cadeia longa e ramificada, (Figura 5) (52).Ele é parte integrante da molécula da clorofila-a, bem como se encontra presente em menor proporção nas clorofilas b, c e d e bacterioclorofila a. Outras possíveis fontes de fitol incluem os fosfolipídeos bacterianos, derivados de glicerol e vitamina K. Além disso, ele pode ser encontrado em ambiente marinho, em óleos vegetais e produtos lácteos derivados de ruminantes. O fitol está ligado no quarto anel da clorofila por meio de uma ligação de éster em sua cadeia lateral e confere a clorofila uma característica lipofílica, representando o lado hidrofóbico da molécula. O que acontece é que a clorofila é 
ancorada na membrana de tilacóide dos cloroplastos por meio da cadeia de fitol (53).

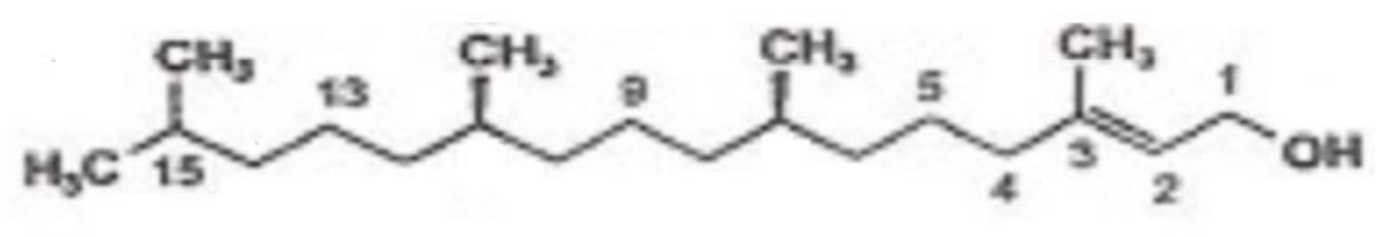

Figura 4. Fórmula estrutural de fitol.

Modificada deAragoni et al (1999).

Em plantas, o fitol é tóxico para as proteínas de membranas devido às suas características detergente (54) que é derivado da quebra da clorofila que é catalizada pela clorofilase (55).

Estudos realizados por (Rontani et al.,1996; Matile et al., 1999 e Rontani e Albert, 2005) sugerem que a degradação do fitol ocorra durante a senescência foliar através da fotooxidação para vários compostos isoprênicos (56-58).

Em humanos a quebra de intermediários do fitol é derivado da dieta ingerida. Por sua vez, o fitol é oxidado em ácido fitânico, que é convertido para fitanoil-CoA por uma cadeia longa de ácido Acil-CoA sintase que é degradado em peroxissomos por um sistema de $\alpha$-oxidação seguido por $\beta$-oxidação em mitocôndrias $(59,60)$.

O fitol e o ácido fitânico podem desempenhar várias funções terapêuticas. Existem relatos na literatura que o fitol e ácido fitânico bloqueiam os efeitos teratogênicos de retinol, sendo úteis na prevenção da teratogenicidade induzida por ingestão excessiva de vitamina A $(61,62)$. Um grupo de pesquisadores evidenciaram que o fitol é capaz de induzir a expressão de genes-alvo envolvidos no tratamento das anormalidades lipídicas em várias doenças comuns, incluindo a obesidade, o diabetes e as dislipidemias (63).

Pesquisas mais recente evidenciaram que o fitol e seus análogos apresentam atividade contra micobactérias e no tratamento da tuberculose, além disso, seus derivados podem ser utilizados para induzir resposta imunológica em humanos, sendo utilizados como adjuvantes em vacinas (64). 
Esse diterpeno também é utilizado na indústria como componente de cosméticos, xampus, sabonetes, detergentes, entre outros. O uso do fitol em nível mundial é 27 aproximadamente de 0,1 a 1,0 toneladas por ano (65).

Ischebeck et al. (2006) através de experimentos com Arabidopsis thaliana, verificou que o fitol livre proveniente da degradação da clorofila é fosforilado em fitil$P$ e fitil-PP. Além disso, o fitil-PP, que é substrato para a síntese de clorofila, filoquinona e tocoferol, seria utilizado como uma via alternativa ou como constituinte de membrana na biossíntese de lipídeos (66) (Figura 6). Porém como não sabemos se o parasito apresenta clorofila, supomos que esse possa ser gerado a partir da degradação das vitaminas E e K1.

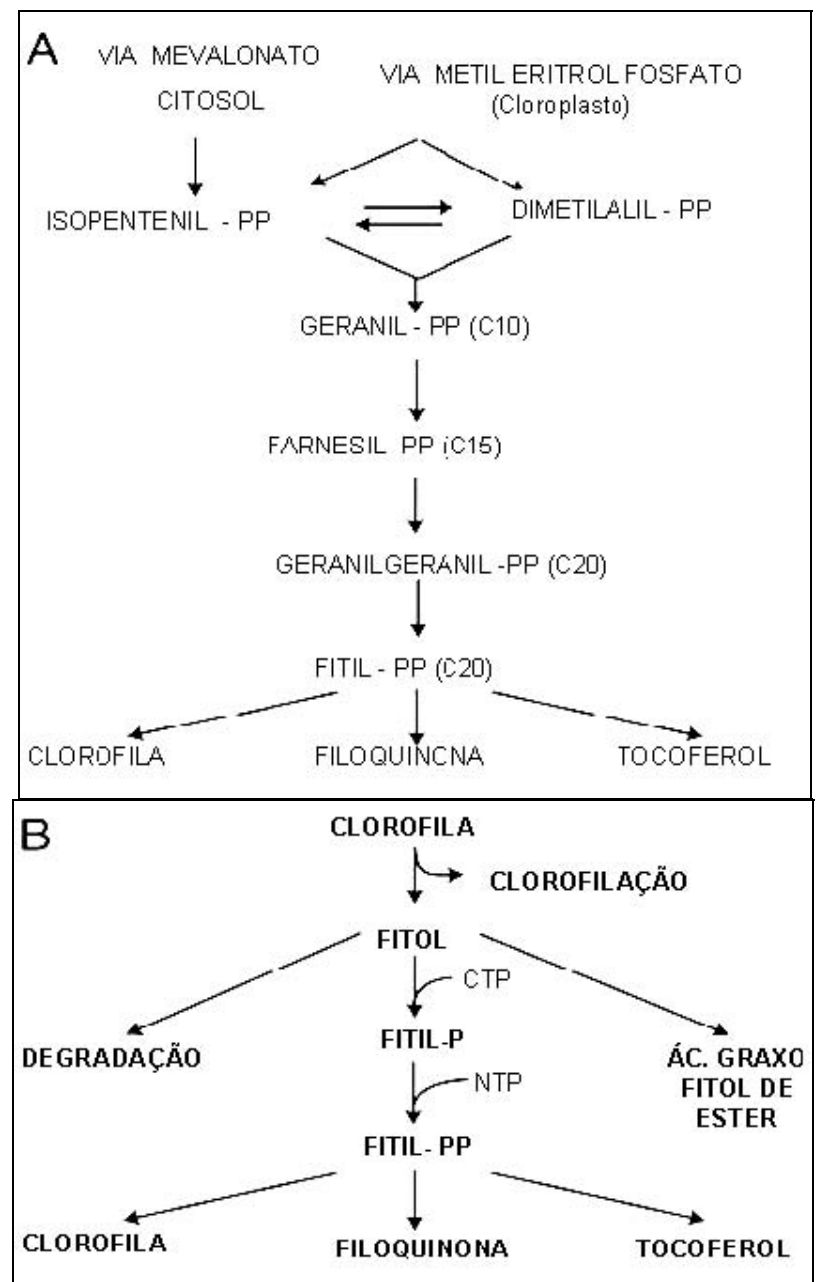

Figura 4. Metabolismo do Fitol em Arabidopsis [A]. O Fitil-PP pode ser biossintetizado através da via do Mevalonato ou metil eritrol fosfato. Posteriormente, Fitil-PP é o substrato para a síntese da clorofila, filoquinona e tocoferol. [B]. O fitol liberado da clorofila por clorofilases pode ser fosforilado por quinase. Além disso, o fitol livre pode ser degradado ou acilado, resultando na produção de ésteres de ácido graxos fitilados. Adaptada do Metabolismo do fitol em Arabidopsis (Ischebeck.; et al. 2006). 


\subsection{O papel das proteínas quinase em Plasmodium falciparum}

As proteínas quinase são responsáveis pela fosforilação e consequentemente, modulação da atividade enzimática. Em P. falciparum, a invasão e o desenvolvimento intraeritrocítico do parasito podem ser inibidos por proteínas quinase (PQs)(67). Estudos sobre as proteínas quinases em malária, bem como, seus reguladores e substratos podem fornecer novos caminhos de desenho de drogas nos estágios intraeritrocíticos (68).

\subsubsection{Proteínas quinase}

As PQs são importantes na sinalização celular pois essas são responsáveis pela modificação do substrato através da fosforilação resultando na mudança de proteína alvo, que podem interferir em sua atividade, localização ou associação com outras proteínas. As quinases são essenciais para o controle do ciclo e diferenciação celular, além de participar do metabolismo celular, na transcrição gênica, no rearranjo do citoesqueleto, do movimento celular e da apoptose. (69).

Koyama et al. (2009), mostrou que as diferentes fases do desenvolvimento do parasito da malária compreendem complexos ciclos de crescimento celular (68) dos quais estima-se que as quinases sejam moduladores fundamentais (70).

As proteínas de membrana de eritrócitos do hospedeiro são conhecidas por serem fosforiladas por proteínas quinase dependentes de $\mathrm{Ca}^{2+}(71)$, e a fosforilação de substratos endógenos e proteínas do hospedeiro foram também observadas no ciclo de vida assexuado (72).

O papel da fosforilação está envolvido em vários estágios do desenvolvimento do parasito, bem como na infecção do hospedeiro, (Zhao et al., 1994; Dluzewski et al., 1996 e Magowan et al.,1998) (67, 71, 73). Existe relatos que implicam a sinalização por cálcio em várias fases do ciclo de vida do parasito, incluindo: esquizogonia eritrocítica, gametogênese, motilidade do oocineto $(74,75)$.

Um estudo realizado em Arabidopsis thailana mostrou que o fitol livre é fosforilado para fitil-P e fitil-PP, por uma atividade fitol quinase (66). 


\subsection{Fitil-PP}

O geralnilgeranil pirofosfato é um precusror da síntese de fitil-PP (76). O fitilPP por sua vez serve como precursor ativo da biossíntese de diferentes lipídeos isoprênicos, incluindo clorofila, tocoferol e filoquinona (66). Além da clorofila, uma classe de ésteres de fitil foi detectada em plantas, conhecido como ácidos graxos de ésteres fitilados (77-79). Ésteres de fitil foram encontrados em bactérias, dinoflagelados, clorófitas, musgos, gramíneas, ervilha e em espécies de plantas da Amazônia (80-84). 
2 JUSTIFICATIVA E OBJETIVO 
A presença de uma via ativa para biossíntese de carotenóides em $P$. falciparum, fez com que nosso grupo de estudo voltasse à atenção para o apicoplasto. Esta organela é similar ao plastídeo de plantas, apresentando o mesmo perfil metabólico da via MEP que é utilizada para biossíntese de carotenóides e vitaminas $A, E$ e $K$, até então considerados exclusivos para a biossíntese de organismos fotossintéticos $(85,86)$.

Nosso grupo de pesquisa demonstrou uma via para a biossíntese de tocoferol e filoquinona nas formas intraeritrocíticas de $P$. falciparum. Estas moléculas possuem uma cadeia lateral fitil-PP provavelmente proveniente da via MEP isoprenóides $(44,66)$. Por sua vez, o fitol formado a partir da degradação de tocoferol e filoquinona, seria ligado a ácidos graxos utilizado como constituinte de membrana, e outra parte sofreria duas fosforilações, gerando posteriormente as vitaminas E e K1 como uma segunda via de biossíntese desse composto, assim como ocorre em Arabidopsis thaliana (66).

Levando em consideração a via de resgate de fitol em Arabidopsis thailana descrita por Ischebeck et al. (2006) (66), nós propusemos:

$\checkmark$ Caracterizar a presença de fitol no ciclo intraeritrocítico de P. falciparum.

$\checkmark$ Verificar a presença de uma segunda via de biossíntese de tocoferol e filoquinona a partir da reciclagem do fitol no ciclo intraeritrocítico de $P$. falciparum.

$\checkmark$ Verificar a fosforilação do fitol formando o fitil-P e fitil-PP através de quinases nas formas intraeritrocíticas de $P$. falciparum. 
3 METODOLOGIA 


\subsection{Cultura de Plasmodium falciparum}

Parasitos de P. falciparum, isolado 3D7, foram cultivados de acordo com o método de Trager e Jensen (87) com as modificações descritas por Kimura et al. (1996) (86). Os parasitos foram cultivados em garrafas de cultivo em meio RPMI1640 suplementado com 25 mM de Hepes, 21 mM de bicarbonato de sódio, $300 \mu \mathrm{M}$ de hipoxantina, $11 \mathrm{mM}$ de glicose, $40 \mu \mathrm{g} / \mathrm{mL}$ de gentamicina e 0,5\% (v/v) de Albumax $^{\circledR}$ (Gibco) Foram adicionados eritrócitos à cultura, obtendo-se um hematócrito de 5\%. As garrafas foram mantidas em estufa a $37^{\circ} \mathrm{C}$, com trocas diárias de meio e injeção de uma mistura gasosa composta por $5 \% \mathrm{CO}_{2}, 5 \% \mathrm{O}_{2} \mathrm{e}$ $90 \% N_{2}$. O controle da parasitemia foi feito com a verificação microscópica diária de esfregaços corados com Giemsa.

\subsection{Sincronização dos parasitos por Plasmagel}

Para sincronizar os parasitos de $P$. falciparum foi realizada uma flotação por Plasmage ${ }^{\circledR}$. Neste sistema, esquizontes e trofozoítos maduros que contém a proteína associada ao knob que são separados dos trofozoítos jovens. Após centrifugação, cada $1 \mathrm{~mL}$ de pellet contendo parasitos, foi adicionado $1,4 \mathrm{ml}$ de RPMI 1640 contendo $0,5 \%$ de Albumax ${ }^{\circledR}$ e 2,4 ml da solução de Plasmagel ${ }^{\circledR} 6 \%(p / v)$ (Laborstoire Roger Bellon, Neuilly sur Seine, France) em solução salina seguido de incubação por 20 minutos a $37^{\circ} \mathrm{C}$. Após incubação, realizou-se outra centrifugação onde os trofozoítos maduros e esquizontes foram separados dos trofozoítos jovens (88).

\subsection{Sincronização dos parasitos por Sorbitol}

Outra metodologia utilizada na sincronização de parasitos foi com sorbitol. Parasitos no estágio de trofozoíto jovem foram centrifugados para remoção do sobrenadante e adição de sorbitol na proporção 1:25 (v/v), precipitado: solução sorbitol $5 \%$ a $37{ }^{\circ} \mathrm{C}$. Após incubação a $37^{\circ} \mathrm{C}$ por 5 minutos, os parasitos foram centrifugados a $800 \times g$ por 10 minutos e o concentrado de parasitos no estágio trofozoíto jovem foi novamente introduzido à cultura (89). 


\subsection{Separação e purificação dos estágios intraeritrocíticos}

Sistema de separacão por coluna - O parasito no estágio de esquizonte foi purificado por uma coluna magnética $\left(\right.$ MACS $^{\circledR}$ Separation Columns - 25 CS columns) (90). Nessa fase, o parasito apresenta hemozoína e $\circ \mathrm{Fe}^{++}$que tem capacidade magnética, faz com que estes fiquem aderidos à coluna magnética, sendo assim purificado (91). Esses parasitos foram eluídos com PBS (30 mM $\mathrm{Na}_{2} \mathrm{HPO}_{4}, 6 \mathrm{mM}$ de $\mathrm{KH}_{2} \mathrm{PO}_{4}, \mathrm{pH} 7,4,120 \mathrm{mM}$ de $\mathrm{NaCl}$ e $11 \mathrm{mM}$ de glicose), centrifugados a $8.000 \times \mathrm{g}$ por 5 minutos, quantificados, congelados em $\mathrm{N}_{2}$ líquido e liofilizados para análises posteriores.

Sistema de separação por gradiente: Os estágios de trofozoíto jovem, trofozoíto maduro e esquizonte, foram separados por gradiente descontínuo de Percoll ${ }^{\circledR}$ (Pharmacia Chemicals, Uppsala, Sweden) 40/70/80\%. Após centrifugação a $10.000 \times g$ durante 30 minutos a $25^{\circ} \mathrm{C}$ formaram-se quatro bandas, sendo a banda superior constituída de parasitos mortos ou merozoítos que não invadiram os eritrócitos. A banda que está entre 40 e $70 \%$ consiste de eritrócitos parasitados com esquizontes, já a banda que está entre 70 e $80 \%$ possui eritrócitos parasitados por trofozoítos maduros, ficando no fundo do tubo apenas os trofozoítos jovens e os eritrócitos não parasitados (92).

Sistema de lise dos eritrócitos - Os esquizontes obtidos de isolados da linhagem 3D7 de $P$. falciparum foram lisados com $0,1 \%(\mathrm{~m} / \mathrm{v})$ de saponina, lavados duas vezes com tampão PBS.

\subsection{Marcações metabólicas}

$\checkmark$ Sistema I - Culturas de P. falciparum no estágio de trofozoíto maduro (30 a 36 horas), com pelo menos $15 \%$ de parasitemia foram incubados com $15 \mu \mathrm{L}$ de $\left[{ }^{3} \mathrm{H}\right]$ pirofosfato de geranilgeranila $\left[{ }^{3} \mathrm{H}\right]-\mathrm{GGPP}$, atividade específica (AE) de $16,5 \mathrm{Ci} / \mathrm{mmol}$ e concentração 3,125 $\mu \mathrm{Ci} / \mathrm{mL}$, foram marcados por 12 a 16 horas (42).

Após a marcação metabólica com cada precursor radioativo, os parasitos no estágio de esquizonte foram purificados por coluna magnética, centrifugados, 
quantificados, congelados em $\mathrm{N}_{2}$, liofilizados e guardados em freezer a $-20{ }^{\circ} \mathrm{C}$ para sua utilização.

Sistema II - Culturas de P. falciparum assincrônicos, com 15\% de parasitemia foram incubados com $15 \mu \mathrm{L}$ de $\left[{ }^{3} \mathrm{H}\right]-\mathrm{GGPP}$ (AE: $16,5 \mathrm{Ci} / \mathrm{mmol}$ e concentração 3,125 $\mathrm{MCi} / \mathrm{mL}$ ) por 12 a 16 horas (34). (93). Após a marcação metabólica, os parasitos foram separados por um gradiente descontínuo Percoll ${ }^{\circledR}$. Posteriormente, os parasitos foram separados em trofozoíto jovem, trofozoíto maduro e esquizonte, congelados em $\mathrm{N}_{2}$, liofilizados e guardados em freezer a -20 ${ }^{\circ} \mathrm{C}$ para sua utilização.

Sistema III - Culturas de P. falciparum no estágio de trofozoíto maduro (30 a 36 horas), com pelo menos $15 \%$ de parasitemia foram incubados com $15 \mu \mathrm{L}$ pirofosfato de farnesila $\left[{ }^{3} \mathrm{H}\right]-\mathrm{FPP},(\mathrm{AE}: 16,5 \mathrm{Ci} / \mathrm{mmol}$ e concentração $0,15 \mu \mathrm{Ci} / \mathrm{mL})$ por 12 a 16 horas (42).

Após a marcação metabólica com cada precursor radioativo, os parasitos no estágio de esquizonte, estes foram purificados por coluna magnética, centrifugados, quantificados, congelados em $\mathrm{N}_{2}$, liofilizados e guardados em freezer a $-20{ }^{\circ} \mathrm{C}$ para sua utilização.

\subsection{Sistemas de cromatografia para caracterização de Fitol e Fitil-PP}

O estudo para identificar a molécula de fitol e fitil-PP foi realizado através de cromatografia líquida de alta eficiência (HPLC) e cromatografia em camada delgada (TLC). Antes da separação realizada por essas técnicas, os parasitos foram extraídos seguindo métodos específicos para cada molécula, como descritos adiante.

\subsubsection{Cromatografia líquida de alta eficiência - HPLC}

Para as análises realizadas por HPLC, foi utilizado uma coluna RP-HPLC Luna $\mathrm{C}_{18}(250 \times 4,6 \mathrm{~mm}, 5 \mu \mathrm{m}$, Phenomenex, CA, USA) em um aparelho Gilson, seguido de uma bomba 322, tendo acoplado a este um modulador de gradiente, 
regulador de temperatura 831, coletor de frações FC203B, e detector de UV 152 (Gilson Villiers-le-Bel, France). A análise foi realizada utilizando o programa UNIPOINT ${ }^{\mathrm{TM}}$ (Gilson Inc.).

Os solventes utilizados para análise por HPLC foram filtrados em membranas de PTFE Phenes Filter Membranes, 0,2 $\mu$, $47 \mathrm{~mm}$ (Phenomenex CA, USA). As amostras antes de serem aplicadas também foram filtradas em filtros de nylon MFS 3, 200PK (Advantec MSF Inc, Ca, USA).

Os padrões de fitol e fitil-PP foram co-injetados junto às amostras radioativas e cromatografados através de HPLC. Estas foram coletadas a cada $1 \mathrm{~mL}$ ou 1,5 mL por minuto (de acordo com a metodologia aplicada), seca em estufa a $50{ }^{\circ} \mathrm{C}$ e adicionado 0,5 mL de líquido de cintilação (Betaplate Scint, Perkin Elmer, Finland), agitadas no vortex por 10 segundos e contadas num aparelho cintilador Beckman.

\subsubsection{Cromatografia de camada delagada - TLC}

$\mathrm{Na}$ cromatografia realizada por TLC foi utilizado placa de vidro $60 \times 20 \times 20$ $\mathrm{cm}$, silica 250-PA TLC (Mallinckrodt Baker, Griesheim, Germany) sendo a fase móvel isopropanol/ $\mathrm{NH}_{4} \mathrm{OH} / \mathrm{H}_{2} \mathrm{O}$ (6:3:1) (66) em cuba de vidro. A cuba foi saturada com o solvente por 3 horas antes do início da cromatografia. Para análise dos compostos marcados com precursores radioativos, utilizou-se placa de detecção autoradiográfica Phosphor Screen (Storage Phosphor Screen, Tritium Screen, Amersham Biosciences) ficando exposta à placa de TLC por 20 dias. A visualização dos padrões nas placas foi realizada através de vapor de iodo.

\subsection{Cuidados no processamento de fitol e fitil-PP}

As moléculas de fitol e fitil-PP são sensíveis à luz podendo degradar facilmente, por isso, alguns cuidados foram tomados durante as extrações e cromatografias. Os vidros foram previamente lavados com ácido nítrico e cobertos com papel alumínio. Os solventes orgânicos foram evaporados sob $\mathrm{N}_{2}$ e o material extraído foi armazenado a $-20{ }^{\circ} \mathrm{C}$. Os trabalhos foram realizados em local com baixa luminosidade. 


\subsection{Extração de fitol}

Sistema I: n-Hexano - Para estudar a presença de fitol, 1,5 x $10^{9}$ esquizontes foram purificados por uma coluna magnética, liofilizados, sonicados e extraídos. O produto liofilizado foi extraído três vezes com $\mathrm{n}$-hexano. Na primeira etapa da extração, foi adicionado $100 \mu \mathrm{L}$ de água, passado no vortex por 30 segundos e então, realizada lise das células através de um utrassom, disruptor de células, por 10 segundos com intervalos de 30 segundos por três vezes e centrifugada a $10.000 \times g$ por 10 minutos a $4{ }^{\circ} \mathrm{C}$. Nas outras etapas, foram adicionados $2 \mathrm{~mL}$ de n-hexano- 0,01\% BHT (hidroxidotolueno butilado), agitadas por 30 segundos no vortex e centrifugado nas mesmas condições. Os sobrenadantes foram transferidos para um único tubo de vidro onde foi seco em nitrogênio (94).

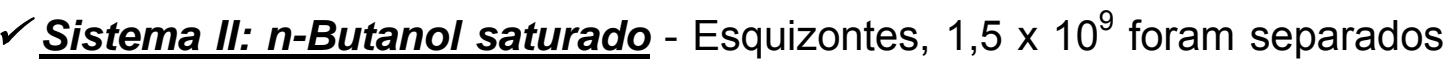
por coluna magnética, liofilizados e extraídos. O produto liofilizado foi extraído três vezes com n-butanol saturado $(1: 1$, v/v) (66). A extração foi iniciada adicionando $1500 \mu \mathrm{L}$ de $\mathrm{n}$-butanol saturado, passado no vortex por 30 segundos e centrifugada a $10.000 \times g$ por 10 minutos a $4{ }^{\circ} \mathrm{C}$. Nas outras duas etapas foi adicionado o mesmo volume do solvente de extração, agitando a amostra por 30 segundos no vortex e centrifugado nas mesmas condições. Os sobrenadantes foram transferidos para um único tubo de vidro onde foi seco em nitrogênio.

\subsubsection{Análise por cromatografia líquida de alta performance - HPLC}

Sistema I: Metanol/ $\mathrm{H}_{2} \mathrm{O}$ (9:1) e metanol/Isopropanol/ $\mathrm{H}_{2} \mathrm{O}$ (2:1:1) - Essa metodologia foi descrita por Low et al., (1991) para identificação de dolicóis de 11 e 12 unidades isoprênicas e adaptada para identificação de fitol (95). Foi utilizado um sistema de gradiente linear tendo como fase móvel o solvente A Metanol/água $\mathrm{MeOH} / \mathrm{H}_{2} \mathrm{O}$ (9:1) e solvente B Metanol/isopropanol/água - MeOH/Isopropanol/ $\mathrm{H}_{2} \mathrm{O}$ (2:1:1) com fluxo de $1,5 \mathrm{~mL} / \mathrm{min}$ por $30 \mathrm{~min}$ (95). Neste sistema, os padrões foram monitorados em um comprimento de onda de $214 \mathrm{~nm}$. 
Sistema Il: acetonitrila e metanol - Esta metodologia de HPLC foi aplicada para identificação de fitol. Foi utilizado um sistema de gradiente linear onde o solvente A, acetonitrila (ACN) $100 \%$ e solvente $\mathrm{B}, \mathrm{MeOH} 100 \%$, com um fluxo de $1 \mathrm{~mL} / \mathrm{min}$ (96). Os padrões foram monitorados em um comprimento de onda de 214 $\mathrm{nm}$.

Sistema III: Bicarbonato de sódio $\left(\mathrm{NaHCO}_{3}{ }_{2}\right.$ e acetonitrila - Essa metodologia foi empregada para identificação de fitol e fitil-PP, consiste de um sistema de gradiente linear, tendo como solvente $\mathrm{A}, \mathrm{NaHCO}_{3}(25 \mathrm{mM})$ e solvente $\mathrm{B}$, ACN $100 \%$, com fluxo de $1,0 \mathrm{~mL} / \mathrm{min}$. Neste sistema, os padrões foram monitorados em um comprimento de onde de $214 \mathrm{~nm}$ (97).

\subsubsection{Cromatografia e recromatografia por HPLC para identificação de fitol}

Sistema I - Aproximadamente, $1,5 \times 10^{9}$ de esquizontes marcados com $\left[{ }^{3} \mathrm{H}\right]$-GGPP, foram separados por coluna magnética, congelados em $\mathrm{N}_{2}$, posteriormente liofilizados e extraídos com $2 \mathrm{~mL}$ de $\mathrm{n}$-hexano e 0,01\% BHT (sistema I de extração de fitol ). As amostras foram eluídas utilizando um sistema de gradiente linear de fase móvel, tendo como solvente $A$ acetonitrila $100 \%$ e solvente B metanol 100\%, com fluxo de $1.0 \mathrm{~mL} / \mathrm{min}$ em $30 \mathrm{~min}$. A amostra correspondente ao tempo de retenção do padrão de fitol (10-11 min) foi coletada, seca em nitrogênio e recromatografada em um sistema de gradiente linear, tendo como solvente $A$ $\mathrm{MeOH} / \mathrm{H}_{2} \mathrm{O}(9: 1)$ e solvente $\mathrm{B} \mathrm{MeOH} / \mathrm{Isop} r o p a n o l / \mathrm{H}_{2} \mathrm{O}(2: 1: 1)$ com fluxo de 1.5 $\mathrm{mL} / \mathrm{min}$ em $25 \mathrm{~min}$, sendo monitorado por um comprimento onda de $214 \mathrm{~nm}$ para identificação de fitol (23).

Sistema II - Aproximadamente, $1,5 \times 10^{9}$ de esquizontes marcados com $\left[{ }^{3} \mathrm{H}\right]$-GGPP e $\left[{ }^{3} \mathrm{H}\right]$-fitol foram separados por coluna magnética, congelados em $\mathrm{N}_{2}$, posteriormente liofilizados e extraídos n-butanol saturado (1:1), sistema II de extração de fitol. Foi utilizado um sistema de gradiente linear de fase móvel HPLC $\left(C_{18}\right)$, tendo como solvente $\mathrm{A} \mathrm{NaHCO}_{3}(25 \mathrm{mM})$ e solvente $\mathrm{B}$ acetonitrila $100 \%$, com fluxo de $1,0 \mathrm{~mL} / \mathrm{min}$ por $60 \mathrm{~min}$ sendo monitorado por um comprimento onda de 214 $\mathrm{nm}$ para identificação da molécula de fitol. A amostra foi coletada e seca em estufa a 
$50^{\circ} \mathrm{C}$, ressuspensa em $0,5 \mathrm{~mL}$ de líquido de cintilação Betaplate scint (PerkinElmer) e contada a incorporação radioativa em um cintilador Beckman (97).

Sistema utilizado: Isopropanol, $\mathrm{NH}_{4} \underline{\mathrm{OH} \text { e } \mathrm{H}_{2}} \underline{\text { O }}$ - A molécula de fitol foi separada em placa de vidro TLC, utilizando isopropanol/ $\mathrm{NH}_{4} \mathrm{OH} / \mathrm{H} 2 \mathrm{O}$ (6:3:1) como fase móvel proposta por Ischebeck et al., (2006). A amostra foi extraída conforme o sistema II do item extração de fitol, e foi exposta para detecção em placa autoradiográfica Phosphor Screen TLC por 20 dias. A visualização dos padrões e seus $R_{f s}$ foram feitos através de vapor de iodo.

\subsection{Extração de Fitil-PP}

Sistema utilizado: $n$-Butanol saturado - Esquizontes, $1,5 \times 10^{9}$ foram separados por coluna magnética, liofilizados, e extraídos. O produto liofilizado foi extraído três vezes com n-butanol saturado (1:1, v/v) (66). A extração, foi iniciada adicionado $1500 \mu \mathrm{L}$ de $\mathrm{n}$-butanol saturado, passado no vortex por $30 \mathrm{~s}$ centrifugada a $10.000 \times g$ por 10 minutos a $4{ }^{\circ} \mathrm{C}$. Nas outras duas etapas, o mesmo volume do solvente de extração foi adicionado, agitando a amostra por 30 segundos no vortex e centrifugado nas mesmas condições. Os sobrenadantes foram transferidos para um único tubo de vidro onde foi seco em nitrogênio. A amostra foi analisada por HPLC.

\subsubsection{Análise de Fitil-PP por HPLC}

Aproximadamente, $1,5 \times 10^{9}$ de esquizontes marcados com [ ${ }^{3} \mathrm{H}$-GGPP ou $\left[{ }^{3} \mathrm{H}\right]$-fitol foram separados por coluna magnética, congelados em $\mathrm{N}_{2}$, liofilizados $\mathrm{e}$ extraídos n-butanol saturado (1:1, v/v). Esta metodologia foi adaptada de Valentin et al., (2006), onde um sistema de gradiente linear de fase móvel HPLC $\left(\mathrm{C}_{18}\right)$, tendo como solvente $\mathrm{A} \mathrm{NaHCO}_{3}(25 \mathrm{mM})$ e solvente $\mathrm{B}$ acetonitrila $100 \%$, com fluxo de 1,0 $\mathrm{mL} / \mathrm{min}$ por 60 min sendo monitorado por um comprimento de onda de $214 \mathrm{~nm}$ para identificação da molécula de fitil-PP. A amostra foi coletada e seca em estufa a 50 ${ }^{\circ} \mathrm{C}$, ressuspensa em $0,5 \mathrm{~mL}$ de líquido de cintilação Betaplate scint (PerkinElmer) e contada a incorporação radioativa em um cintilador Beckman (97). 


\subsection{Ensaios de fosforilação do fitol}

$\checkmark$ Preparação do extrato de proteína - Aproximadamente $1 \mathrm{~mL}$ de parasitos no estágio de esquizontes foram lisados com $0,1 \%(\mathrm{~m} / \mathrm{v})$ de saponina, centrifugados a $5000 \times g$ por 5 minutos a $4{ }^{\circ} \mathrm{C}$ e lavados duas vezes com PBS. Após lise dos eritrócitos, foi adicionado $300 \mu \mathrm{L}$ do tampão contendo: $100 \mathrm{mM}$ Tris-HCl; $\mathrm{pH} 7.5 ; 1$ $\mathrm{mM}$ ditiotreitol (DDT); $1 \mathrm{mM} \mathrm{MgCl}$; $1 \mathrm{mM}$ isoascorbato; $1 \mathrm{mM} \mathrm{KCl} ; 0,1 \%$ albumina de soro bovino e Coquetel inibidor de protease - Sigma Aldrich (USA). Estes parasitos foram congelados e descongelados em nitrogênio líquido por 4 vezes, depois realizada a lise das células através de um utrassom - disruptor de células - 10 segundos com intervalos de 30 segundos por três vezes. Os parasitos foram centrifugados a $100.000 \times g$ por $30 \mathrm{~min}$ a $4^{\circ} \mathrm{C}(66)$.

Caracterização da atividade quinase para fosforilação de fitol - Esta metodologia foi modificada de Ischebeck et al. (2006) e adaptada de Eggens et al. (1988) (98). Após centrifugação a $100.000 \times$ g, formou-se uma fração de membrana e outra citoplasmática solúvel na qual foram analisados separadamente por HPLC. A cada uma destas foi adicionado $300 \mu \mathrm{L}$ do tampão de reação contendo: $50 \mathrm{mM}$ de $\mathrm{MgCl}_{2}$; 20mM NaF; 50 mM de Tris- $\mathrm{HCl}$ pH 8.0; 20 mM de ortovanato de sódio; $1 \mathrm{mM}$ de DTT e $50 \mathrm{mM}$ de $\mathrm{CaCl}_{2}$; seguido de $\left[{ }^{3} \mathrm{H}\right]$-fitol $(20 \mathrm{Ci} / \mathrm{mmol})$ e os nucleotídeos (NTPs) trifosfato de adenosita (ATP), trifosfato de citidina (CTP), trifosfato de uridina (UTP) e trifosfato de guanidina (GTP) com concentração de 200 mM (99). Após 60 min de incubação a $37^{\circ} \mathrm{C}$, a reação foi parada com $300 \mu \mathrm{L}$-butanol saturado (1:1, $\mathrm{v} / \mathrm{v}$ ) e centrifugado a $10.000 \times \mathrm{g}$ por $10 \mathrm{~min}$ por três vezes. Nas outras duas etapas foram adicionados mesmo volume de n-butanol saturado $(1: 1, v / v)$, agitando a amostra por 30 segundos no vortex e centrifugado nas mesmas condições. Os sobrenadantes foram transferidos para um único tubo de vidro onde foi seco em nitrogênio. A amostra foi analisada por HPLC.

\subsubsection{Análise da atividade de fitol quinase por HPLC}

Sistema: $\mathrm{NaHCO}_{3}(25 \mathrm{mM})$ e $\mathrm{ACN}$ - Foi utilizado um sistema de gradiente linear HPLC $\left(C_{18}\right)$, tendo como solvente $A, \mathrm{NaHCO}_{3}(25 \mathrm{mM})$ e solvente $B, A C N$ 
100\%. O sistema iniciou-se com $30 \%$ do solvente B e mudando para $100 \%$ do mesmo no tempo de (0-20 min). Foi mantido um fluxo de $100 \%$ do solvente $B$ durante (20-39 $\mathrm{min}$ ) voltando para o sistema inicial em (39-40 $\mathrm{min}$ ), com fluxo de 1,0 $\mathrm{mL} / \mathrm{min}$ por $30 \mathrm{~min}$, sendo monitorado por um comprimento onda de $214 \mathrm{~nm}$ para identificação de fitol e fitil-PP (97). A amostra foi coletada, seca em estufa a $50^{\circ} \mathrm{C}$ e ressuspensa em $0,5 \mathrm{~mL}$ de líquido de cintilação Betaplate scint (PerkinElmer) e contada a incorporação radioativa em um cintilador Beckman. 
4 RESULTADOS 


\subsection{Sistema I de HPLC}

Foi padronizado um sistema de RP-HPLC, tendo como fase móvel $\mathrm{MeOH} / \mathrm{H} 2 \mathrm{O}$ (9:1) e $\mathrm{MeOH} /$ isopropanol/H2O (2:1:1), que mostrou-se eficiente para identificar fitol. Os padrões co-injetados apresentaram os seguintes tempos de retenção: 7-8 min para geranilgeranil-PP, 10-11 min para fitol, 18-19 min para menaquinona (Vitamina K2) e Tocoferol (Vitamina E) e 24-25 min para filoquinona (Vitamina K1). Nessas condições, foram cromatografados $1,5 \times 10^{9}$ parasitos marcados metabolicamente com o precursor radioativo $\left[{ }^{3} \mathrm{H}\right]-\mathrm{GGPP}$ e foram separados dos eritrócitos não parasitados por purificação através de coluna magnética e extraídos utilizando (sistema I de extração). Foram observadas frações radioativas nas amostras coletadas, sendo estas coincidentes com os tempos de retenção dos padrões geranilgeranil-PP, fitol e das vitaminas $E, K_{2}$ e $K_{1}$ respectivamente (figura 6 ).

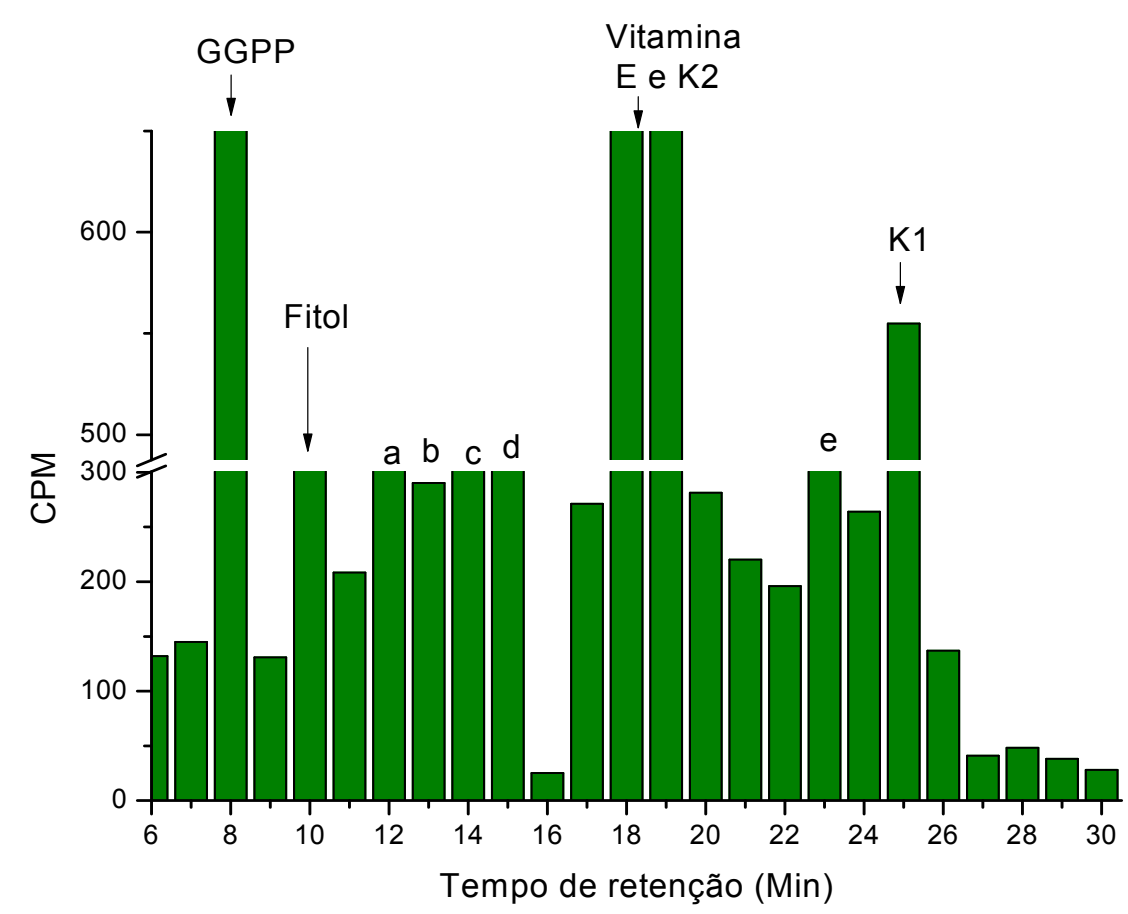

Figura 5. Perfil de eluição radioativa por HPLC. $1,5 \times 10^{9}$ de parasitos marcados metabolicamente com precursor radioativo $\left[{ }^{3} \mathrm{H}\right]$-GGPP. As amostras foram extraídas com $\mathrm{n}-\mathrm{Hexano}$ e cromatografadas em uma coluna $\mathrm{C}_{18}$. Os tempos de retenção dos padrões co-injetados: Geranilgeranil-PP (GGPP), Fitol, Tocoferol (vitamnina E) , Menaquinona (vitamnina K2). As barras representam a quantidade de radioatividade medida para cada minuto coletado na cromatografia. As frações não identificadas estão representadas pelas letras a, b, c, d, e.

Utilizando ainda o sistema I de HPLC, já descrito, extrato de parasitos assincrônicos (trofozoíto jovem, trofozoíto maduro e esquizonte) foram 
cromatografados após serem marcados metabolicamente com o precursor radioativo $\left[{ }^{3} \mathrm{H}\right]-$ GGPP e separados por gradiente descontínuo Percoll ${ }^{\circledR}$ dos eritrócitos não parasitados, e então, extraídos com o sistema I de extração.

Foram observadas frações radioativas nas amostras coletadas (Figura 7, A B, C), confirmada através da co-injeção dos padrões comerciais.

A)

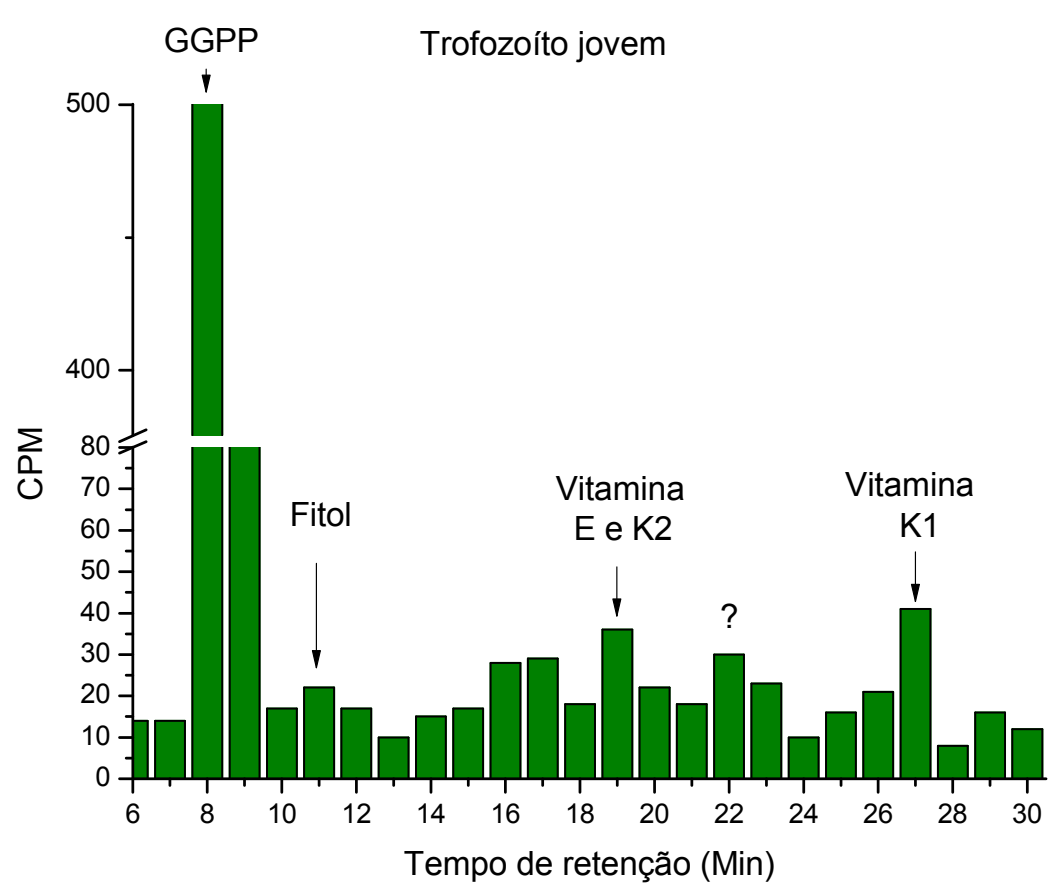

B)

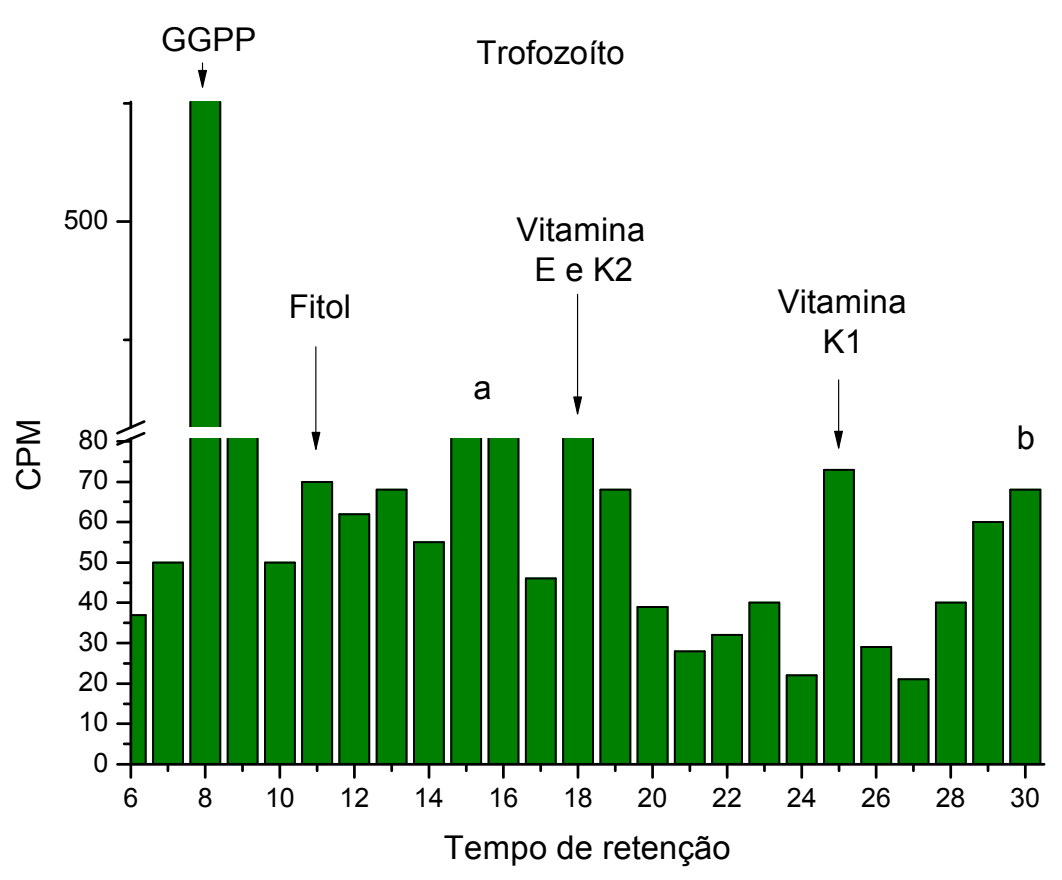


C)

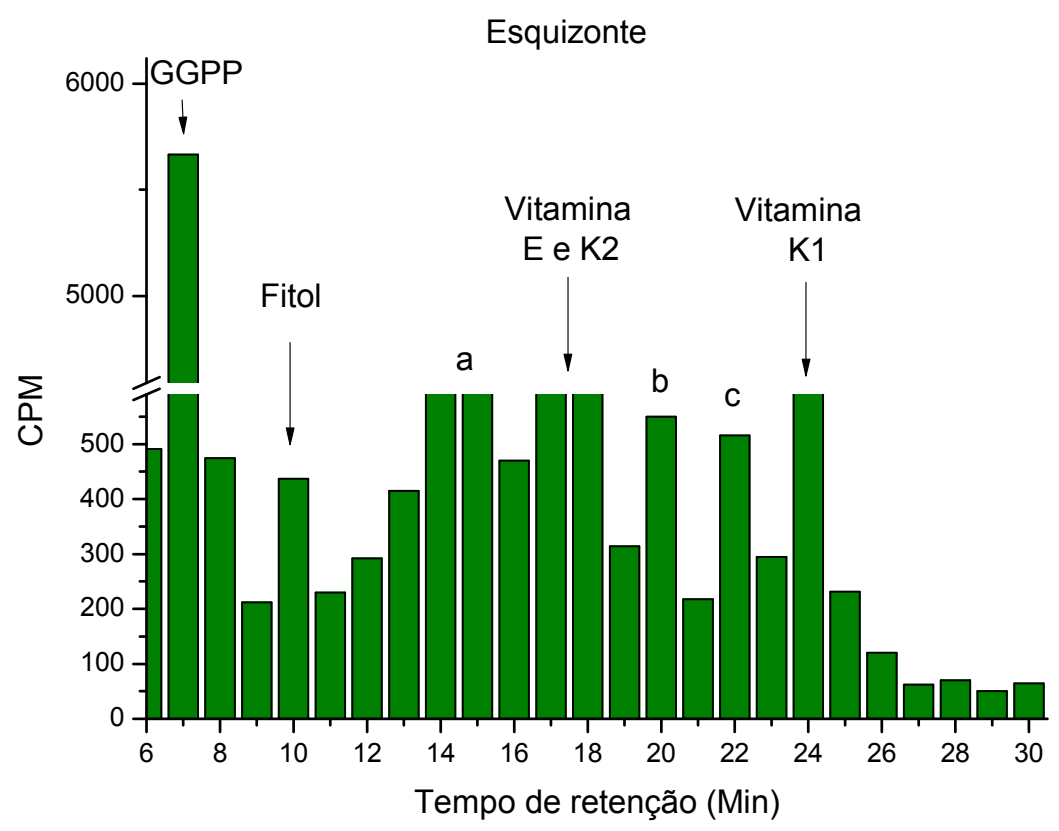

Figura 6. Perfil de eluição radioativa de parasitos marcados metabolicamente com [3H]-GGPP. (A) Trofozoíto jovem, (B) trofozoíto maduro, (C) esquizonte separados por gradiente desccontínuo Percol. Todas as formas foram extraídas com nhexano e purificado por RP-HPLC. A fração radioativa foi identificada por co-injeção de padrões comerciais GGPP; Fitol, Vitaminas K2, E e K1. As frações não identificadas estão representadas pelas letras a, b, c.

\subsection{Sistema II de HPLC}

Outro RP-HPLC foi padronizado para confirmar a presença de fitol no parasito. Através de um sistema de gradiente, tendo como fase móvel ACN $100 \%$ e $\mathrm{MeOH} 100 \%$. Uma concentração de $1,5 \times 10^{9}$ parasitos foram cromatografados após serem marcados metabolicamente com o precursor radioativo $\left[{ }^{3} \mathrm{H}\right]$-GGPP e separados dos eritrócitos não parasitados por purificação através de coluna magnética, e extraídos com n-hexano (sistema I de extração). As frações correspondentes ao tempo de retenção do padrão de fitol (11-12 min) foram coletadas, secas em nitrogênio, ressuspensas em n-hexano e recromatografadas no (sistema I de RP-HPLC) descrito acima. Foi realizada a co-injeção do padrão comercial do fitol e das frações coletadas, foi medida a radioatividade como mostrado na (Figura 8). 


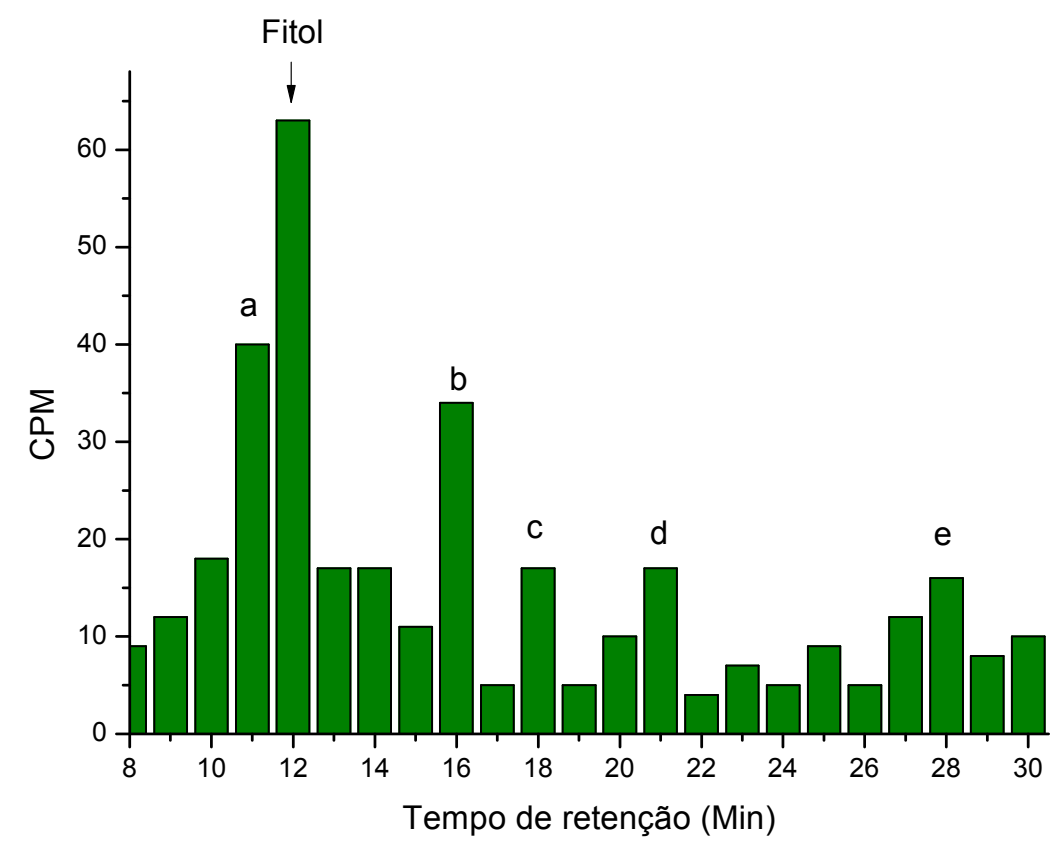

Figura 7. Perfil de eluição radioativa em parasitos marcados metabolicamente com [3H]-GGPP. Os esquizontes foram purificados por coluna magnética e extraído com n-hexano, cromatografado no (sistema II) e recromatografado no (sistema I) RP-HPLC. A fração radioativa foi identificada por co-injeção dos padrões comerciais de GGPP; Fitol, Vitaminas K2, E e K1.

\subsection{Análise de fitol e fitil-PP por HPLC}

Para identificar as moléculas de fitol e fitil-PP, foi utilizado um sistema de RPHPLC gradiente linear composto de $\mathrm{NaHCO}_{3}(25 \mathrm{mM})$ e ACN 100\%. Os padrões coinjetados apresentaram os seguintes tempos de retenção: 9-10 min para geranilgeranil-PP, 12-13 min para fitil-PP, 42-43 min para fitol. Nestas condições, foram cromatografados $1,5 \times 10^{9}$ parasitos marcados metabolicamente com $\mathrm{O}$ precursor radioativo $\left[{ }^{3} \mathrm{H}\right]$-GGPP que foram separados dos eritrócitos não parasitados por purificação através de coluna, e então, extraídos com n-butanol (sistema II de extração). Das frações coletadas, foi medida a radioatividade e o resultado foi mostrado na (Figura 10).

Foi observada uma contagem radioativa nas frações coletadas coincidentes com o tempo de retenção dos padrões comerciais de GGPP, fitil-PP e fitol respectivamente. 


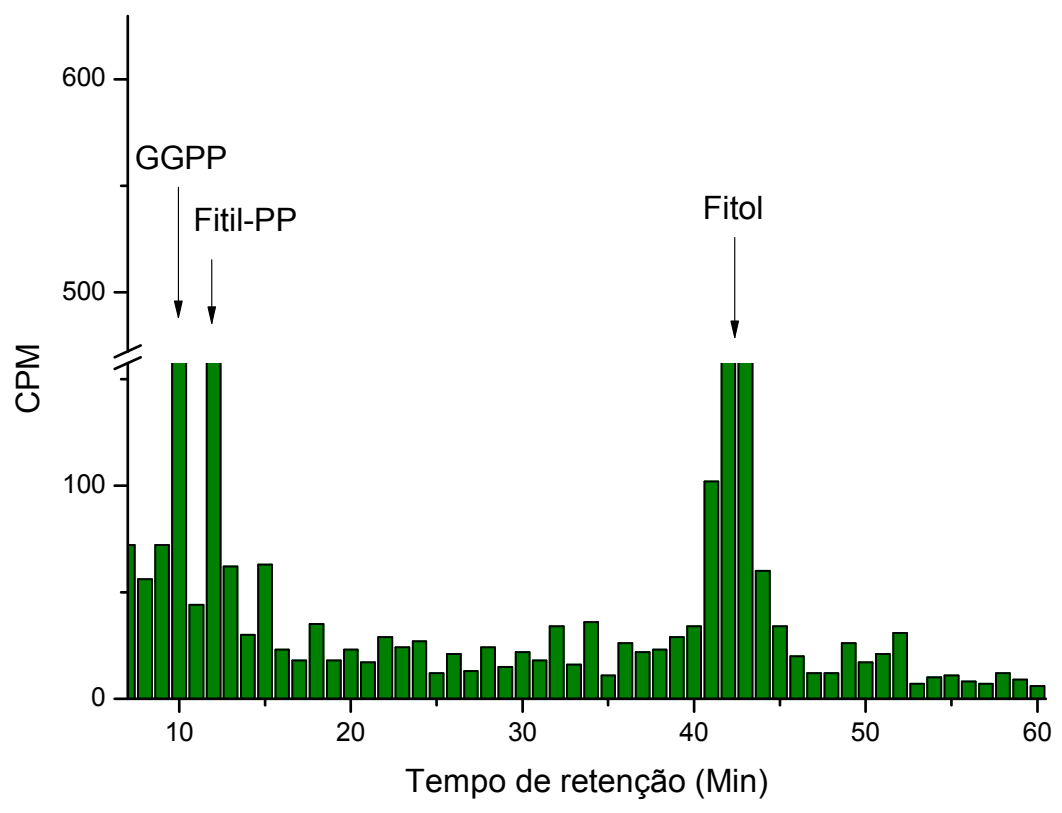

Figura 8.Perfil de eluição radioativa em parasitos marcados metabolicamente com $\left.{ }^{3} \mathrm{H}\right]$-GGPP. Os esquizontes purificados por coluna magnética e extraído com n-butanol saturado (1:1) v/v sendo identificado por RP-HPLC (sistema III).O pico de retenção foi identificado por co-injeção dos padrões comerciais de GGPP, fitil-PP e fitol.As frações não identificadas estão representadas pelas letras a, b, c, d, e.

\subsection{Análise de fitol por cromatografia TLC}

O sistema utilizado para TLC capaz de separar os padrões de GGPP e fitol foi composto $\mathrm{NH}_{4} \mathrm{OH}$ / isopropanol/água (6:3:1)

Uma concentração de $1,5 \times 10^{9}$ parasitos marcados metabolicamente com os precursores radioativos $\left[{ }^{3} \mathrm{H}\right]$-GGPP ou $\left[{ }^{3} \mathrm{H}\right]$-FPP foi separada dos eritrócitos não parasitados por purificação através de coluna, e então, extraídos com n-butanol (sistema II de extração). As bandas observadas mostraram um $\mathrm{R}_{f}$ 0,96, 0,80 e 0,51, para Fitol, GGPP e FPP respectivamente (Figura 11). 


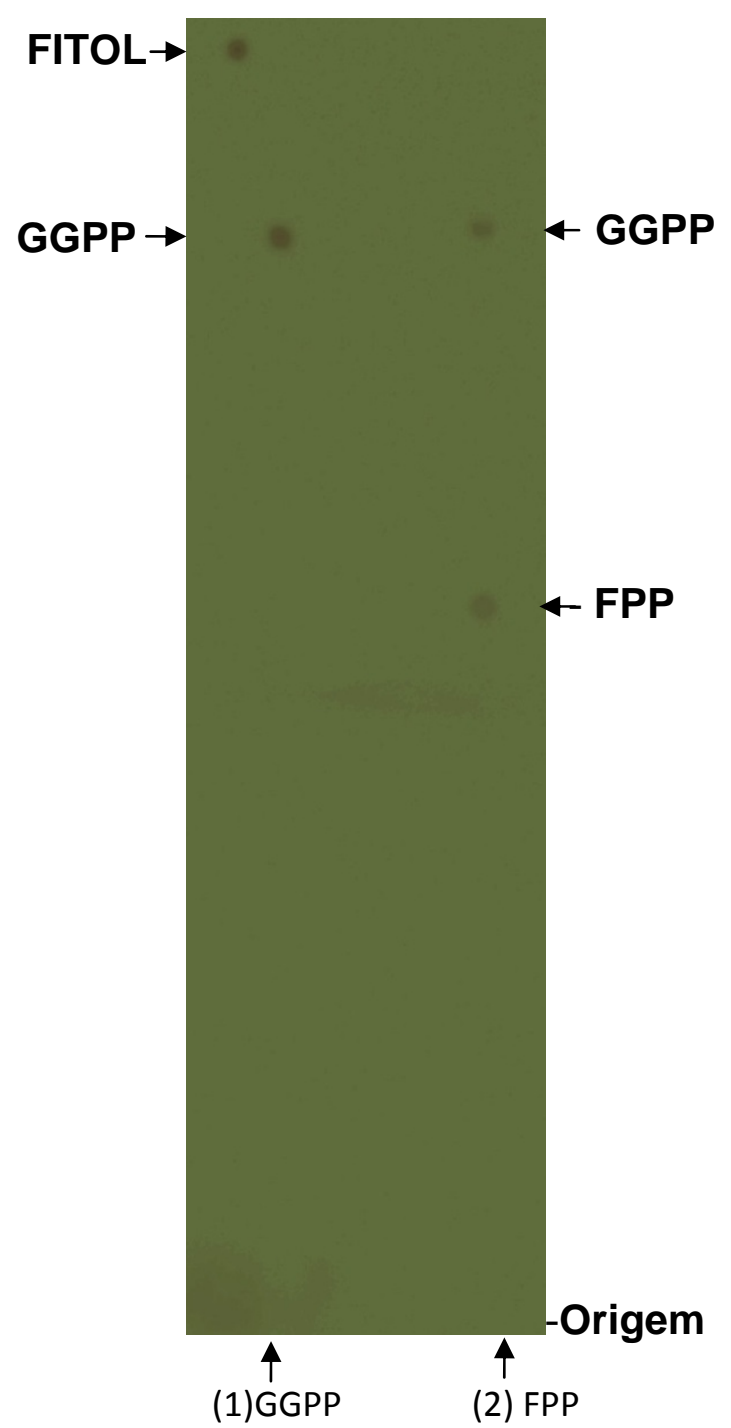

Figura 9. Autoradiografia de parasitos marcados metabolicamente com $(1)\left[^{3} \mathrm{H}\right]$-GGPP e (2) $\left[^{3} \mathrm{H}\right]$-FPP. Foram analisados $1,5 \times 10^{9}$ esquizontes para ambas marcações, extraídos com n-butanol (sistema II de extração) e cromatografado em TLC. Os padrões estão indicados pelo nome.

Tabela 1 Valores dos $\mathrm{R}_{f}$ de produtos da via de isoprenóides cromatografada em TLC para a análise de fitol utilizando como solvente: Isopropanol $/ \mathrm{NH}_{4} \mathrm{OH} / \mathrm{H}_{2} \mathrm{O}(6: 3: 1)$

\begin{tabular}{cc}
\hline Padrões & $\mathbf{R}_{\boldsymbol{f}}$ \\
\hline Fitol & 0,96 \\
GGPP & 0,80 \\
FPP & 0,51 \\
\hline
\end{tabular}




\subsection{Atividade enzimática de fitol quinase}

Para avaliar a atividade enzimática de fitol quinase nas frações: citoplasmática solúvel e de membrana, foi utilizado um sistema RP-HPLC descrito no (item 4.1) - gradiente linear composto de $\mathrm{NaHCO}_{3}$ (25 mM) e ACN 100\%. Os padrões co-injetados apresentaram os seguintes tempos de retenção: 9-10 min para fitil-PP 12-13 min para fitil-P e 35-36 min para fitol. Das frações coletadas, observouse uma fração radioativa correspondente ao fitol, fitil-P e fitil-PP respectivamente (Figura $11 \mathrm{~A}$ e $\mathrm{B}$ ).

A

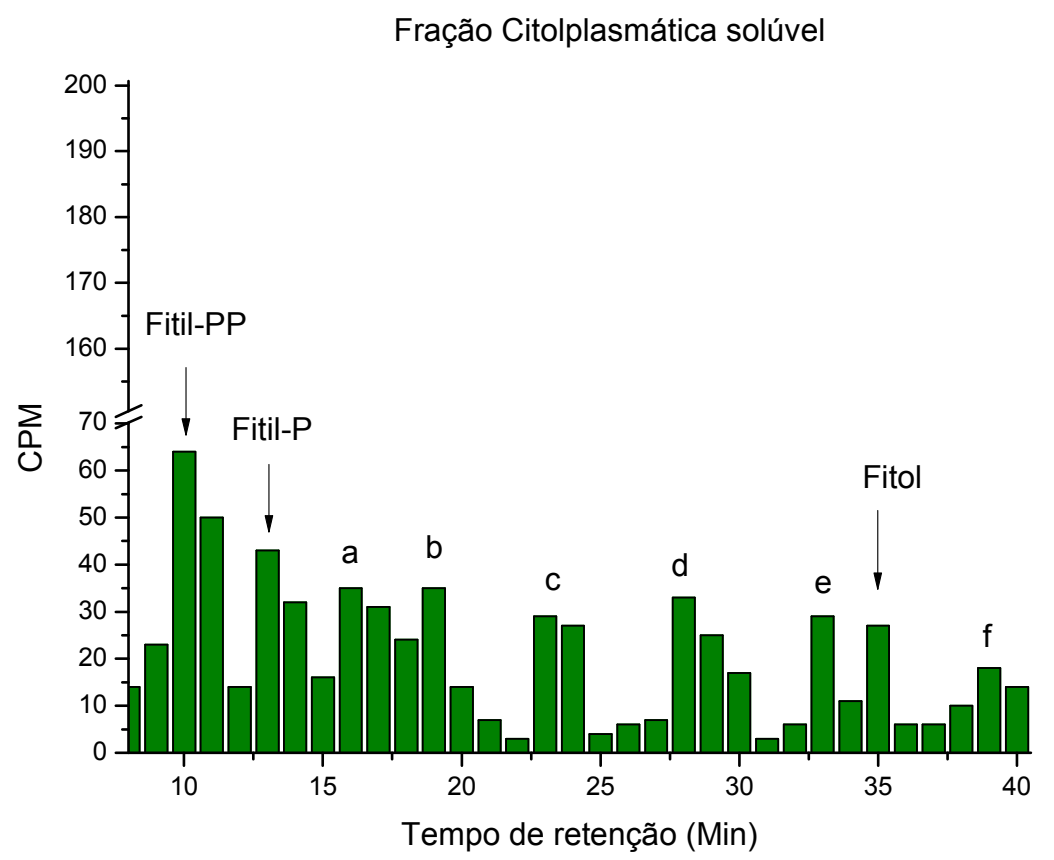




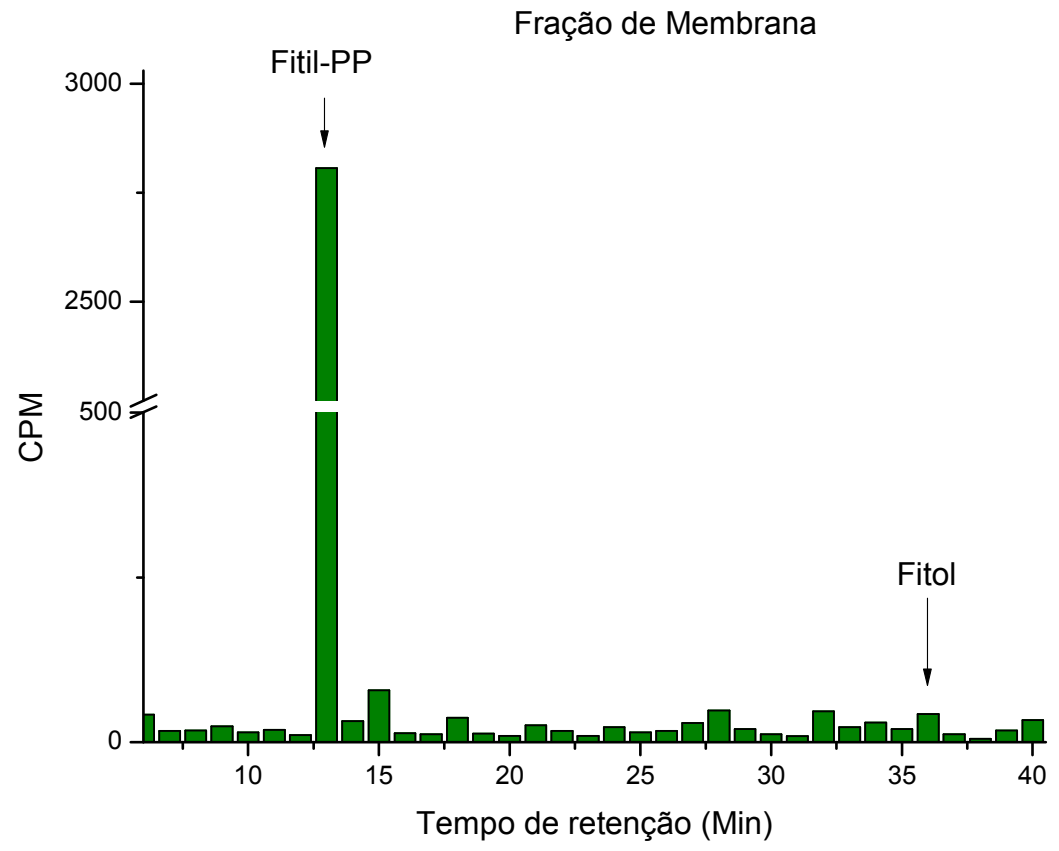

Figura 10. A e B Perfil de eluição radioativa do ensaio de fosforilação do fitol formando fitil-P e fitil-PP. Os esquizontes foram separados através de por lise por saponina e posteior centrifugação e extraído com n-butanol (1:1) v/v sendo identificado por RP-HPLC (sistema III).O pico de retenção foi identificado por co-injeção dos padrões comerciais di $\mathrm{PP}$ e fitol. As frações não identificadas estão representadas pelas letras a, b, c, d, e, f . 
5 DISCUSSÃO 
Demostrar a presença de fitol e suas formas fosforiladas em $P$. falciparum foram importantes para conhecer mais sobre a biologia do parasito, bem como, confirmar a presença de filoquinona e tocoferol.

A identificação de fitol em $P$. falciparum foi feita por através de marcação metabólica utilizando diferentes sistemas cromatográficos. Utilizamos precursores radioativos para amplificar o resultado, uma vez que há dificuldade na obtenção de grandes quantidades de parasitos. O pirofasfato de geranilgeranila foi escolhido como precursor metabólico por ser um intermediário da via de isoprenóides.

Inicialmente foi utilizado um sistema isocrático de RP-HPLC, tendo como sovente $\mathrm{MeOH} / \mathrm{H}_{2} \mathrm{O}$ em diferentes concentrações: 100\%; (90:10) e (95:5) mas esses não mostraram-se eficientes. Em alguns sistemas o fitol coeluiu com outro composto, o geranilgeraniol (GGOH), previamente identificado no parasito. Em outra cromatografia não possível a visualização do padrão comercial de fitol. Uma justificativa seria a variação da polaridade da fase móvel, influenciando assim na capacidade de retenção e separação da molécula de fitol.

$\mathrm{Na}$ tentativa de eliminar os problemas de coeluição do fitol com outras moléculas marcadas metabolicamente com [ $\left.{ }^{3} \mathrm{H}\right]$-GGPP, o sistema isocrático foi substituído por um sistema de gradiente linear, RP-HPLC.

Nos sistemas de RP-HPLC ensaiados, foram determinados os tempos de retenção dos seguintes compostos: a-tocoferol, filoquinona, menaquinona, pirofosfato de farnesila, pirofosfato de geranilgeranila, fitil-PP, fitol, compostos isoprênicos garantindo a não coeluição entre eles quando marcados com o precursor metabólico [ $\left.{ }^{3} \mathrm{H}\right]-\mathrm{GGPP}$.

Duas das três metodologias estabelecidas para identificação de fitol por RPHPLC sistema I e II, inicialmente foram utilizadas por nosso grupo de pesquisa para identificação de dolicóis e vitamina $\mathrm{E}(94,95)$. Porém, estas se mostraram eficientes para a identificação da molécula de fitol (Figura 6, 8), inclusive, nos três estágios intraeritrocíticos (Figura 7). A terceira e última metodologia utilizada para identificação de fitol e seus produtos fosforilados (Figura 9) foi proposta por Valentin et al.; (2006). Com isso, foram padronizadas duas novas metodologias para identificação de fitol.

A cromatografia por TLC é a técnica mais encontrada na literatura para a identificação de fitol, contudo, os primeiros ensaios realizados não foram 
satisfatórios. Essa não identificação de fitol pode estar relacionada às adaptações feitas ao método de extração $(100,101)$. Mas, ao marcar parasitos metabolicamente com o precursor radioativo [ $\left.{ }^{3} \mathrm{H}\right]$-GGPP, a molécula de fitol foi separada em placa de vidro TLC, utilizando uma mistura de isopropanol/ $\mathrm{NH}_{4} \mathrm{OH} / \mathrm{H} 2 \mathrm{O}(6: 3: 1)$ como fase móvel proposta na literatura (66) foi confirmada a presença de fitol no parasito. No entanto, quando foi disponibilizado o precursor radioativo $\left[{ }^{3} \mathrm{H}\right]-\mathrm{FPP}$ em meio de cultura não foi observada a presença de fitol. O que pode ter ocorrido é que o pirofosfato de farnesila não seja precursor para formação dessa molécula (Figura 10).

Portanto, como não existem evidências da presença de clorofila no parasito e em quaisquer outros organismos que não seja fotossintético, sugerimos que o fitol seja originado da degradação da filoquinona e do tocoferol.

Um trabalho realizado em camundongos salienta a hipótese de o fitol seja originado da degradação da vitamina $\mathrm{K} 1$. Demonstrando que ocorre uma dessaturação da cadeia fitil ligada à filoquinona, que por sua vez se converte em menaquinona (102). Não sabemos se o mesmo ocorre em Plasmodium falciparum, contudo, quando ocorrer a dessaturação da cadeia lateral fitil, essa perde sua dupla ligação formando assim uma nova molécula. Portanto, acreditamos que essa nova molécula formada possa ser fitol, reforçando a hipótese de que este composto seja formado a partir da degradação da vitamina K1, como sugerido (Figura 12). Embora não existam trabalhos relacionados com formação de fitol a partir do tocoferol essa hipótese não está descartada, uma vez que a vitamina $E$ possui a cadeia lateral fitilPP (44).

Embora o fitol livre não seja um intermediário para a biossíntese de isoprenóides, em plantas ele é gerado pela clorofilase durante o estresse ou senescência $(57,66,103,104)$, mas pouco se conhece sobre o seu destino metabólico $(57,103,104)$. Em plantas e cianobactérias o fitol é um constituinte para ambos os tocoferóis (vitaminas E), e compreende também a vitamina K1 (105)

Portanto, para verificar uma via de resgate para biossíntese de tocoferol e filoquinona a partir do fitol, Sussmann, aluno de doutorado do nosso grupo de pesquisa marcou metabolicamente culturas de parasitos com $\left[{ }^{3} \mathrm{H}\right]$-Fitol e $\left[{ }^{3} \mathrm{H}\right]$-Fitil-PP e analisou através de HPLC. Os picos radioativos coincidentes com os tempos de retenção dos padrões comerciais de $\alpha$-tocoferol, $\gamma^{-}$tocoferol e filoquinona foram 
detectados na fase de esquizonte de $P$. falciparum (dados não publicados). Esses dados fundamentam os resultados apresentados neste trabalho, mostrando que o parasito é capaz de fosforilar fitol em fitil-P e fitil-PP e de biossintetizar as vitaminas K1 e E a partir do fitol como ocorre em Arabidopsis (66).

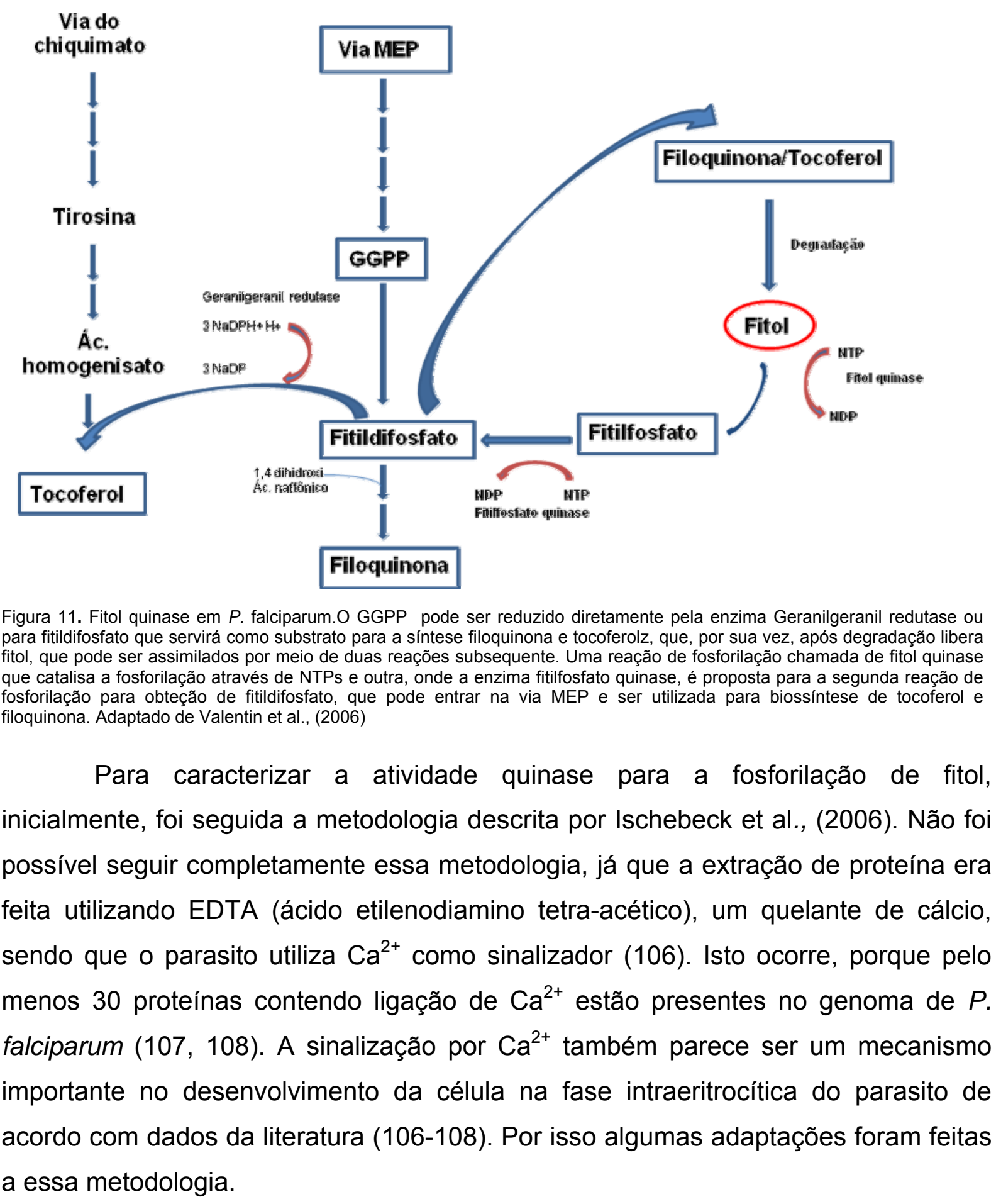


Nós mostramos que em extrato de proteínas de $P$. falciparum ocorre a fosforilação de fitol, como foi registrado por Valentin et al., (2006) e Ischebeck et al., (2006) em Arabidopsis, quando utilizou o precursor metabólico [ ${ }^{3} \mathrm{H}$ ]-Fitol. Sabendo que se faz necessário a presença de um doador fosfato para ocorrer atividade fitol quinase, utilizamos os nucleotídeos ATP, CTP, UTP e GTP. Porém, neste trabalho, devido à falta de tempo hábil, não foi possível identificar qual o nucleotídeo responsável por essa transferência do grupo fosfato como mostrado no trabalho de Ischebeck et al., (2006) e Valentin et al., (2006), onde fitol quinase é dependente de CTP. Diversos trabalhos mostram fosforilação de álcoois isoprenóides tendo o CTP como doador fosfato (109-114).

Os dados apresentados de RP-HPLC, somado a TLC, em que as frações radioativas foram correspondentes ao tempo de retenção do padrão comercial de fitol, confirmam a presença da molécula de fitol no parasito. Corroborando com os resultados apresentados neste trabalho, Rodrigo Sussmann do nosso laboratório, confirmou a presença de fitol em $P$. falciparum através de analises por espectometria de massa GC-M (dados não publicados).

Os ensaios de reação enzimática mostram claramente que fitol pode ser convertido para fitil-P e fitil-PP e posteriormente empregado para síntese de tocoferol e filoquinona. Corroborando com os dados de descritos por Ischebeck et al. (2006). Na fração de membrana, a fosforilação de $\left[{ }^{3} \mathrm{H}\right]$-fitol mostra que fitol quinase possui uma grande atividade para fitil-P (Figura 12B). Na fração citoplasmática solúvel observou-se que o $\left[{ }^{3} \mathrm{H}\right]$-fitol poder ser fosforilado em fitil-P e fitil-PP como mostrado na (Figura 12A). Como não dispomos do padrão comercial de fitil-P, supomos que essa fração radioativa correspondente a esta molécula, baseado no trabalho descrito por Valentin et al., (2006)(97).

Contudo, com este estudo ainda não podemos afirmar qual a função do fitol, onde ele se encontra, qual é doador fosfato específico e a enzima responsável pela sua fosforilação. Portanto, sugerimos que ele possa estar ligado a ácidos graxos utilizados como constituinte de membrana (66) e que a fitol quinase seja dependente de CTP $(66,97)$, que a enzima que catalisa a segunda reação seja uma citidiltransferase, porém, outros estudos precisam ser realizados para essa confirmação. 
6 CONCLUSÃO 
$\checkmark$ A presença de fitol observa por RP-HPLC e TLC, sendo confirmada espectometria de massa no parasito (dados não publicados).

Os resultados mostram uma atividade de fitol quinase em $P$. falciparum.

$\checkmark$ Sugere-se que o fitol seja formado a partir da degradação da vitamina E e K1 podendo ser reciclado para a biossíntese de tocoferol e filoquinona. 
REFERÊNCIAS 


\section{REFERÊNCIAS ${ }^{1}$}

1. Bowman S, Lawson D, Basham D, Brown D, Chillingworth T, Churcher CM, et al. The complete nucleotide sequence of chromosome 3 of Plasmodium falciparum. Nature. 1999 Aug 5;400(6744):532-8.

2. Greenwood B. The molecular epidemiology of malaria. Trop Med Int Health. 2002 Dec;7(12):1012-21.

3. Krettli AU, Andrade-Neto VF, Brandao MGL, Ferrari WMS. The search for new antimalarial drugs from plants used to treat fever and malaria or plants randomly selected: A

review. Mem I Oswaldo Cruz. 2001 Nov;96(8):1033-42.

4. Sawyer DR, Sawyer DRT. Malaria on the Amazon frontier : economic and social aspects of transmission and control. Belo Horizonte: Centro de Desenvolvimento e Planejamento Regional, Faculdade de Ciências Econômicas-UFMG; 1987.

5. Trigg PI, Kondrachine AV. Commentary: Malaria control in the 1990s. B World Health Organ. 1998;76(1):11-6.

6. White NJ. Antimalarial drug resistance. J Clin Invest. 2004 Apr;113(8):1084-92.

7. Ginsburg H, Ward SA, Bray PG. An integrated model of chloroquine action. Parasitol Today. 1999 Sep;15(9):357-60.

8. Bekker M, Kramer G, Hartog AF, Wagner MJ, de Koster CG, Hellingwerf KJ, et al. Changes in the redox state and composition of the quinone pool of Escherichia coli during aerobic batchculture growth. Microbiology. 2007 Jun;153(Pt 6):1974-80.

9. Slater AFG, Cerami A. Inhibition by Chloroquine of a Novel Heme Polymerase EnzymeActivity in Malaria Trophozoites. Nature. 1992 Jan 9;355(6356):167-9.

10. Warhurst DC. The quinine-haemin interaction and its relationship to antimalarial activity. Biochem Pharmacol. 1981 Dec 15;30(24):3323-7.

11. Macreadie I, Ginsburg H, Sirawaraporn W, Tilley L. Antimalarial drug development and new targets. Parasitol Today. 2000 Oct;16(10):438-44.

12. Phillips RS. Current status of malaria and potential for control. Clin Microbiol Rev. 2001 Jan;14(1):208-26.

13. Greenwood B, Mutabingwa T. Malaria in 2002. Nature. 2002 Feb 7;415(6872):670-2.

\footnotetext{
${ }^{1}$ De acordo com:

International Committee of Medical J ournal Editors. [Internet]. Uniform requirements for manuscripts submitted to Biomedical Journal: sample references. [updated $2011 \mathrm{~J} \mathrm{ul} \mathrm{15].} \mathrm{Available} \mathrm{from:}$ http://www.icmje.org
} 
14. Sherman I. Pathogenesis and protection. Malaria Parasite biology 1998;Washington, DC:ASM.

15. Phillips RS. Current status of malaria and potential for control. Clin Microbiol Rev. 2001 Jan;14(1):208-26.

16. Bruce-Chwatt LJ. Epidemiology of malaria. In Essential malariology, London: William Heinemann Medical Books Ltd. 1980:129-68.

17. Reis L. Parasitologia. 4. ed. Rio de Janeiro: Guanabara Koogan; 2008.

18. Menard R. The journey of the malaria sporozoite through its hosts: two parasite proteins lead the way. Microbes Infect. 2000 May;2(6):633-42.19. Fast NM, Kissinger JC, Roos DS, Keeling PJ. Nuclear-encoded, plastid-targeted genes suggest a single common origin for apicomplexan and dinoflagellate plastids. Mol Biol Evol. 2001 Mar;18(3):418-26.

20. Wilson RJ. Progress with parasite plastids. J Mol Biol. 2002 May 31;319(2):257-74.

21. Tonhosolo R, D'Alexandri FL, Genta FA, Wunderlich G, Gozzo FC, Eberlin MN, et al. Identification, molecular cloning and functional characterization of an octaprenyl pyrophosphate synthase in intra-erythrocytic stages of Plasmodium falciparum. Biochem J. 2005 Nov 15;392 (Pt1):117-26.

22. Couto AS, Kimura EA, Peres VJ, Uhrig ML, Katzin AM. Active isoprenoid pathway in theintra-erythrocytic stages of Plasmodium falciparum: presence of dolichols of 11 and 12 isoprene units. Biochem J. 1999 Aug 1;341 ( Pt 3):629-37.

23. Michal G. Biochemical Pathways. An Atlas of Biochemestry and Molecular Biology.1999;1 ed.

24. Flesch G, Rohmer M. Prokaryotic hopanoids: the biosynthesis of the bacteriohopane skeleton. Formation of isoprenic units from two distinct acetate pools and a novel type of carbon/carbon linkage between a triterpene and D-ribose. Eur J Biochem. 1988 Aug 1;175(2):405-11.

25. Goldstein JL, Brown MS. Regulation of the mevalonate pathway. Nature. 1990 Feb 1;343(6257):425-30.

26. Eisenreich W, Bacher A, Arigoni D, Rohdich F. Biosynthesis of isoprenoids via the nonmevalonate pathway. Cell Mol Life Sci. 2004 Jun;61(12):1401-26.

27. Mbaya B, Rigomier D, Edorh GG, Karst F, Schrevel J. Isoprenoid metabolism in Plasmodium falciparum during the intraerythrocytic phase of malaria. Biochem Biophys Res Commun. 1990 Dec 31;173(3):849-54.

28. Moura IC, Wunderlich G, Uhrig ML, Couto AS, Peres VJ, Katzin AM, et al. Limonene arrests parasite development and inhibits isoprenylation of proteins in Plasmodium falciparum. Antimicrob Agents Chemother. 2001 Sep;45(9):2553-8.

29. Jomaa H, Wiesner J, Sanderbrand S, Altincicek B, Weidemeyer C, Hintz M, et al.Inhibitors of the nonmevalonate pathway of isoprenoid biosynthesis as antimalarial drugs. Science. 1999 Sep;285(5433):1573-6. 
30. Cassera MB, Gozzo FC, D'Alexandri FL, Merino EF, del Portillo HA, Peres VJ, et al. The methylerythritol phosphate pathway is functionally active in all intraerythrocytic stages of Plasmodium falciparum. J Biol Chem. 2004 Dec 10;279(50):51749-59.

31. Moura IC, Wunderlich G, Uhrig ML, Couto AS, Peres VJ, Katzin AM, et al. Limonene arrests parasite development and inhibits isoprenylation of proteins in Plasmodium falciparum. Antimicrob Agents Ch. 2001 Sep;45(9):2553-8.

32. de Macedo CS, Uhrig ML, Kimura EA, Katzin AM. Characterization of the isoprenoid chain of coenzyme $Q$ in Plasmodium falciparum. Fems Microbiol Lett. 2002 Jan 22;207(1):13-20.

33. D'Alexandri FL, Kimura EA, Peres VJ, Katzin AM. Protein dolichylation in Plasmodium falciparum. Febs Lett. 2006 Nov 27;580(27):6343-8.

34. Tonhosolo R, Gabriel HB, Matsumura MY, Cabral FJ, Yamamoto MM, D'Alexandri FL, et al. Intraerythrocytic stages of Plasmodium falciparum biosynthesize menaquinone. Febs Lett. 2010 Dec 1;584(23):4761-8.

35. Carson CF, Riley TV. Antimicrobial activity of the major components of the essential oil of Melaleuca alternifolia. J Appl Bacteriol. 1995 Mar;78(3):264-9.

36. Hammer KA, Carson CF, Riley TV. In vitro activity of Melaleuca alternifolia (tea tree) oil against dermatophytes and other filamentous fungi. J Antimicrob Chemother. 2002 Aug;50(2):195-9.

37. Goulart HR, Kimura EA, Peres VJ, Couto AS, Duarte FAA, Katzin AM. Terpenes arrest parasite development and inhibit biosynthesis of isoprenoids in Plasmodium falciparum. Antimicrob Agents Ch. 2004 Jul;48(7):2502-9.

38. Tonhosolo R, D'Alexandri FL, de Rosso VV, Gazarini ML, Matsumura MY, Peres VJ, et al. Carotenoid biosynthesis in intraerythrocytic stages of Plasmodium falciparum. J Biol Chem. 2009. Apr 10;284(15):9974-85.[

39. Herrmann KM, Weaver LM. The Shikimate Pathway. Annu Rev Plant Physiol Plant Mol Biol. 1999 Jun;50:473-503.

40. McConkey GA, Ittarat I, Meshnick SR, McCutchan TF. Auxotrophs of Plasmodium falciparum dependent on p-aminobenzoic acid for growth. Proc Natl Acad Sci U S A. 1994 May 10;91(10):4244-8.

41. Roberts F, Roberts CW, Johnson JJ, Kyle DE, Krell T, Coggins JR, et al. Evidence for the shikimate pathway in apicomplexan parasites. Nature. 1998 Jun 25;393(6687):801-5.

42. Olson RE. The function and metabolism of vitamin K. Annu Rev Nutr. 1984;4:281-337.43. Michael G. Biochemical Pathways. An Atlas of Biochemestry and Molecular Biology.1999.

44. Wang X, Quinn PJ. Vitamin E and its function in membranes. Prog Lipid Res. 1999 Jul;38(4):309-36.

45. Ischebeck $T$, Zbierzak AM, Kanwischer $M$, Dormann P. A salvage pathway for phytol metabolism in Arabidopsis. J Biol Chem. 2006 Feb 3;281(5):2470-7. 
46. Schneider C. Chemistry and biology of vitamin E. Mol Nutr Food Res. 2005 Jan;49(1):7-30

47. Wolf $\mathrm{G}$. The discovery of the antioxidant function of vitamin $\mathrm{E}$ : The contribution of Henry A. Mattill. J Nutr. 2005 Mar;135(3):363-6.

48. Sussmann RAC, Angeli CB, Peres VJ, Kimura EA, Katzin AM. Intraerythrocytic stages of Plasmodium falciparum biosynthesize vitamin E. Febs Lett. 2011 Dec 15;585(24):3985-91.

49. Gross J, Cho WK, Lezhneva L, Falk J, Krupinska K, Shinozaki K, et al. A plant locus essential for phylloquinone (vitamin K1) biosynthesis originated from a fusion of four eubacterial genes. J Biol Chem. 2006 Jun 23;281(25):17189-96.

50. Iverson TM, Luna-Chavez C, Cecchini G, Rees DC. Structure of the Escherichia coli fumarate reductase respiratory complex. Science. 1999 Jun 18;284(5422):1961-6.

51. Gabriel HB. Caracterização da função biológica da vitamina K biossintetizada pelas formas intraeritrocitárias de Plasmodium falciparum Dissertação (Mestrado) - USP, São Paulo - SP. 2010:87.

52. McGinty D, Letizia CS, Api AM. Fragrance material review on phytol. Food Chem Toxicol. 2010 Jan;48 Suppl 3:S59-63.

53. Rontani JF, Volkman JK. Phytol degradation products as biogeochemical tracers in aquatic environments. Org Geochem. 2003;34(1):1-35.

54. Lippold F, vom Dorp K, Abraham M, Holzl G, Wewer V, Yilmaz JL, et al. Fatty acid phytyl ester synthesis in chloroplasts of Arabidopsis. Plant Cell. 2012 May;24(5):2001-14.

55. Tsuchiya T, Ohta H, Okawa K, Iwamatsu A, Shimada H, Masuda T, et al. Cloning of chlorophyllase, the key enzyme in chlorophyll degradation: finding of a lipase motif and the induction by methyl jasmonate. Proc Natl Acad Sci U S A. 1999 Dec 21;96(26):15362-7.

56. Rontani JF, Cuny P, Grossi V. Photodegradation of chlorophyll phytyl chain in senescent leaves of higher plants. Phytochemistry. 1996 May;42(2):347-51.

57. Matile P, Hortensteiner S, Thomas H. Chlorophyll Degradation. Annu Rev Plant Physiol Plant Mol Biol. 1999 Jun;50:67-95.

58. Rontani JFA, C. Characterization of isomeric allylic diols resulting from chlorophyll phytyl sidechain photo- and autoxidation by electron ionization gas chromatography/mass spectrometry. Rapid Commun Mass Spectrom. 2005;19(5):637-46.

59. Wierzbicki AS, Lloyd MD, Schofield CJ, Feher MD, Gibberd FB. Refsum's disease: a peroxisomal disorder affecting phytanic acid alpha-oxidation. J Neurochem. 2002 Mar;80(5):727-35.

60. Wanders RJ, Jansen GA, Lloyd MD. Phytanic acid alpha-oxidation, new insights into an old problem: a review. Biochim Biophys Acta. 2003 Mar 17;1631(2):119-35.

61. Arnhold T, Elmazar MMA, Nau H. Prevention of vitamin A teratogenesis by phytol or phytanic acid results from reduced metabolism of retinol to the teratogenic metabolite, all-trans-retinoic acid. Toxicol Sci. 2002 Apr;66(2):274-82. 
62. Aachoui Y, Schulte ML, Fitch RW, Ghosh SK. Synthetic adjuvants for vaccine formulations: Evaluation of new phytol derivatives in induction and persistence of specific immune response. Cell Immunol. 2011;271(2):308-18.

63. Goto T, Takahashi N, Kato S, Egawa K, Ebisu S, Moriyama T, et al. Phytol directly activates peroxisome proliferator-activated receptor alpha (PPARalpha) and regulates gene expression involved in lipid metabolism in PPARalpha-expressing HepG2 hepatocytes. Biochem Biophys Res Commun. 2005 Nov 18;337(2):440-5.

64. Saikia D, Parihar S, Chanda D, Ojha S, Kumar JK, Chanotiya CS, et al. Antitubercular potential of some semisynthetic analogues of phytol. Bioorg Med Chem Lett. 2010 Jan 15;20(2):508-12.

65. IFRA. (International Fragrance Association) Use Level Survey. 2004.

66. Ischebeck T, Zbierzak AM, Kanwischer M, Dormann P. A salvage pathway for phytol metabolism in Arabidopsis. J Biol Chem. 2006 Feb 3;281(5):2470-7.

67. Dluzewski AR, Garcia CR. Inhibition of invasion and intraerythrocytic development of Plasmodium falciparum by kinase inhibitors. Experientia. 1996 Jun 15;52(6):621-3.

68. Koyama FC, Chakrabarti D, Garcia CR. Molecular machinery of signal transduction and cell cycle regulation in Plasmodium. Mol Biochem Parasitol. 2009 May;165(1):1-7.

69. Hanks SK. Genomic analysis of the eukaryotic protein kinase superfamily: a perspective. Genome Biol. 2003;4(5):111.

70. Anamika, Srinivasan N, Krupa A. A genomic perspective of protein kinases in Plasmodium falciparum. Proteins. 2005 Jan 1;58(1):180-9.

71. Zhao Y, Franklin RM, Kappes B. Plasmodium falciparum calcium-dependent protein kinase phosphorylates proteins of the host erythrocytic membrane. Mol Biochem Parasitol. 1994 Aug;66(2):329-43.

72. Jones GL, Edmundson HM. Protein phosphorylation during the asexual life cycle of the human malarial parasite Plasmodium falciparum. Biochim Biophys Acta. 1990 Jul 12;1053(2-3):11824.

73. Magowan C L, Yeung J, Takakuwa Y, Coppel RL, Mohandas N. Plasmodium falciparum: influence of malarial and host erythrocyte skeletal protein interactions on phosphorylation in infected erythrocytes. Exp Parasitol. 1998;89:40-9.

74. Billker O, Dechamps S, Tewari R, Wenig G, Franke-Fayard B, Brinkmann V. Calcium and a calcium-dependent protein kinase regulate gamete formation and mosquito transmission in a malaria parasite. Cell. 2004 May 14;117(4):503-14.

75. Marchesini N, Luo S, Rodrigues CO, Moreno SN, Docampo R. Acidocalcisomes and a vacuolar $\mathrm{H}+$-pyrophosphatase in malaria parasites. Biochem J. 2000 Apr 1;347 Pt 1:243-53.

76. Lichtenthaler HK. The 1-Deoxy-D-Xylulose-5-Phosphate Pathway of Isoprenoid Biosynthesis in Plants. Annu Rev Plant Physiol Plant Mol Biol. 1999 Jun;50:47-65. 
77. Peisker C. DgT, Rentsch D., Matile P. Phytol and the breakdown of chlorophyll in senescent leaves. Journal of Plant Physiology 1989;135:428-32.

78. Csupor.L. Das phytol in vergilbten Blättern. Plant Med. 1971;19:37-40.

79. Patterson GW, Hugly, S., and Harrison, D. Sterol and phytyl ester in Arabidopsis thaliana under normal and chilling temperatures Phytochemistry. 1993;33:1381-3.

80. Gellerman JL AW, Schlenk H. Synthesis and analysis of phytyl and phytenoyl wax esters. Lipids. 1975;10(656-661).

81. Rontani JF, Bonin PC, Volkman JK. Production of wax esters during aerobic growth of marine bacteria on isoprenoid compounds. Appl Environ Microbiol. 1999 Jan;65(1):221-30.

82. Cranwell PA, Robinson, N., and Eglinton, G. Esterified lipids oh the freshwater dinoflagellated Peridinium lomnickii. Lipids. 1985;20:645-51.

83. Cranwell PAJGHMBHM. Hydrocarbons, sterols, esters and fatty acids in six freshwater chlorophytes. Phytochemistry. 1990;29:145-51.

84. Pereira AS, Siqueira DS, Elias VO, Simoneit BR, Cabral JA, Aquino Neto FR. Three series of high molecular weight alkanoates found in Amazonian plants. Phytochemistry. 2002 Nov;61(6):711-9.

85. Seeber F. Biosynthetic pathways of plastid-derived organelles as potential drug targets against parasitic apicomplexa. Curr Drug Targets Immune Endocr Metabol Disord. 2003 Jun;3(2):99109.

86. Kimura EA, Couto AS, Peres VJ, Casal OL, Katzin AM. N-linked glycoproteins are related to schizogony of the intraerythrocytic stage in Plasmodium falciparum. J Biol Chem. 1996 Jun 14;271(24):14452-61.

87. Trager $\mathrm{W}$, Jensen JB. Continuous culture of Plasmodium falciparum: its impact on malaria research. Int J Parasitol. 1997 Sep;27(9):989-1006.

88. Goodyer ID, Johnson J, Eisenthal R, Hayes DJ. Purification of Mature-Stage PlasmodiumFalciparum by Gelatin Flotation. Ann Trop Med Parasit. 1994 Apr;88(2):209-11.

89. Lambros C, Vanderberg JP. Synchronization of Plasmodium falciparum erythrocytic stages in culture. J Parasitol. 1979 Jun;65(3):418-20.

90. Trang DT, Huy NT, Kariu T, Tajima K, Kamei K. One-step concentration of malarial parasiteinfected red blood cells and removal of contaminating white blood cells. Malar J. 2004 Mar 17;3:7.

91. Hackett S, Hamzah J, Davis TM, St Pierre TG. Magnetic susceptibility of iron in malariainfected red blood cells. Biochim Biophys Acta. 2009 Feb;1792(2):93-9.

92. Braun-Breton C, Jendoubi M, Brunet E, Perrin L, Scaife J, Pereira da Silva L. In vivo time course of synthesis and processing of major schizont membrane polypeptides in Plasmodium falciparum. Mol Biochem Parasitol. 1986 Jul;20(1):33-43. 
93. D'Alexandri FL, Kimura EA, Peres VJ, Katzin AM. Protein dolichylation in Plasmodium falciparum. FEBS Lett. 2006 Nov 27;580(27):6343-8.

94. Gueguen S, Herbeth B, Siest G, Leroy P. An isocratic liquid chromatographic method with diode-array detection for the simultaneous determination of alpha-tocopherol, retinol, and five carotenoids in human serum. J Chromatogr Sci. 2002 Feb;40(2):69-76.

95. Low P, Dallner G, Mayor S, Cohen S, Chait BT, Menon AK. The mevalonate pathway in the bloodstream form of Trypanosoma brucei. Identification of dolichols containing 11 and 12 isoprene residues. J Biol Chem. 1991 Oct 15;266(29):19250-7.

96. Chatzimichalakis PF, Samanidou VF, Papadoyannis IN. Development of a validated liquid chromatography method for the simultaneous determination of eight fat-soluble vitamins in biological fluids after solid-phase extraction. J Chromatogr B Analyt Technol Biomed Life Sci. 2004 Jun 15;805(2):289-96.

97. Valentin HE, Lincoln K, Moshiri F, Jensen PK, Qi Q, Venkatesh TV, et al. The Arabidopsis vitamin E pathway gene5-1 mutant reveals a critical role for phytol kinase in seed tocopherol biosynthesis. Plant Cell. 2006 Jan;18(1):212-24.

98. Eggens I, Ericsson J, Tollbom O. Cytidine 5'-triphosphate-dependent dolichol kinase and dolichol phosphatase activities and levels of dolichyl phosphate in microsomal fractions from highly differentiated human hepatomas. Cancer Res. 1988 Jun 15;48(12):3418-24.

99. Ischebeck $T$, Zbierzak AM, Kanwischer $M$, Dormann P. A salvage pathway for phytol metabolism in Arabidopsis. J Biol Chem. 2006 Feb 3;281(5):2470-7.

100. Brown AE, Lascelles J. Phytol and Bacteriochlorophyll Synthesis in Rhodopseudomonas spheroides. Plant Physiol. 1972 Dec;50(6):747-9.

101. Bling EGaD, W.J A rapid method of total lipid extraction and purufucation. Can J Biochemical physiology. 1959;37((8)):p.912-7. .

102. Okano $T$, Shimomura $Y$, Yamane $M$, Suhara $Y$, Kamao $M$, Sugiura $M$, et al. Conversion of phylloquinone (Vitamin K1) into menaquinone-4 (Vitamin K2) in mice: two possible routes for menaquinone-4 accumulation in cerebra of mice. J Biol Chem. 2008 Apr 25;283(17):11270-9.

103. Hortensteiner S. Chlorophyll breakdown in higher plants and algae. Cell Mol Life Sci. 1999 Oct 15;56(3-4):330-47.

104. Krautler B. Unravelling chlorophyll catabolism in higher plants. Biochem Soc Trans. 2002 Aug;30(4):625-30.

105. Shibata M, Tsuyama M, Takami T, Shimizu H, Kobayashi Y. Accumulation of menaquinones with incompletely reduced side chains and loss of alpha-tocopherol in rice mutants with alternations in the chlorophyll moiety. J Exp Bot. 2004 Sep;55(405):1989-96.

106. Garcia CR. Calcium homeostasis and signaling in the blood-stage malaria parasite. Parasitol Today. 1999 Dec;15(12):488-91. 
107. Gazarini ML, Thomas AP, Pozzan T, Garcia CR. Calcium signaling in a low calcium environment: how the intracellular malaria parasite solves the problem. J Cell Biol. $2003 \mathrm{Apr}$ 14;161(1):103-10.

108. Varotti FP, Beraldo FH, Gazarini ML, Garcia CR. Plasmodium falciparum malaria parasites display a THG-sensitive Ca2+ pool. Cell Calcium. 2003 Feb;33(2):137-44.

109. Bentinger M, Grunler J, Peterson E, Swiezewska E, Dallner G. Phosphorylation of farnesol in rat liver microsomes: Properties of farnesol kinase and farnesyl phosphate kinase. Archives of Biochemistry and Biophysics. 1998 May 15;353(2):191-8.

110. Thai L, Rush JS, Maul JE, Devarenne T, Rodgers DL, Chappell J, et al. Farnesol is utilized for isoprenoid biosynthesis in plant cells via farnesyl pyrophosphate formed by successive monophosphorylation reactions. P Natl Acad Sci USA. 1999 Nov 9;96(23):13080-5.

111. Ohnuma $\mathrm{S}$, Watanabe $\mathrm{M}$, Nishino $\mathrm{T}$. Identification and characterization of geranylgeraniol kinase and geranylgeranyl phosphate kinase from the archaebacterium Sulfolobus acidocaldarius. J Biochem-Tokyo. 1996 Mar;119(3):541-7.

112. Heller L, Orlean P, Adair WL, Jr. Saccharomyces cerevisiae sec59 cells are deficient in dolichol kinase activity. Proc Natl Acad Sci U S A. 1992 Aug 1;89(15):7013-6.

113. Inoue $\mathrm{H}$, Korenaga $\mathrm{T}$, Sagami H, Koyama $\mathrm{T}$, Ogura K. Phosphorylation of Farnesol by a CellFree System from Botryococcus-Braunii. Biochem Bioph Res Co. 1994 Apr 29;200(2):1036-41.

114. Westfall D, Aboushadi N, Shackelford JE, Krisans SK. Metabolism of farnesol: phosphorylation of farnesol by rat liver microsomal and peroxisomal fractions. Biochem Biophys Res Commun. 1997 Jan 23;230(3):562-8. 